\title{
Current glacier recession causes significant rockfall increase: The immediate paraglacial response of deglaciating cirque walls
}

Ingo Hartmeyer ${ }^{1}$, Robert Delleske ${ }^{1}$, Markus Keuschnig ${ }^{1}$, Michael Krautblatter ${ }^{2}$, Andreas Lang ${ }^{3}$, Lothar Schrott $^{4}$, Jan-Christoph Otto ${ }^{3}$

$5 \quad{ }^{1}$ GEORESEARCH Research Institute, Wals, 5071, Austria

${ }^{2}$ Chair of Landslide Research, Technical University of Munich, Munich, 80333, Germany

${ }^{3}$ Department of Geography and Geology, University of Salzburg, Salzburg, 5020, Austria

${ }^{4}$ Department of Geography, University of Bonn, Bonn, 53115, Germany

Correspondence to: Ingo Hartmeyer (ingo.hartmeyer@georesearch.ac.at)

10 Abstract. In the European Alps almost half the glacier volume disappeared over the past 150 years. The loss is reflected in glacier retreat and ice surface lowering even at high altitude. In steep glacial cirques surface lowering exposes rock to atmospheric conditions for the very first time in many millennia. Instability of rockwalls has long been identified as one of the direct consequences of deglaciation, but so far cirque-wide quantification of rockfall at high-resolution is missing. Based on terrestrial LiDAR a rockfall inventory for the permafrost-affected rockwalls of two rapidly deglaciating cirques in the Central

15 Alps of Austria (Kitzsteinhorn) is established. Over six-years (2011-2017) 78 rockwall scans were acquired to generate data of high spatial and temporal resolution. 632 rockfalls were registered ranging from 0.003 to $879.4 \mathrm{~m}^{3}$, mainly originating from pre-existing structural rock weaknesses. $60 \%$ of the rockfall volume detached from less than ten vertical meters above the glacier surface, indicating enhanced rockfall activity over tens of years following deglaciation. Debuttressing seems to play a minor effect only. Rather, preconditioning is assumed to start inside the Randkluft (gap between cirque wall and glacier) where

20 sustained freezing and ample supply of liquid water likely cause enhanced physical weathering and high plucking stresses. Following deglaciation, pronounced thermomechanical strain is induced and an active layer penetrates into the formerly perennially frozen bedrock. These factors likely cause the observed paraglacial rockfall increase close to the glacier surface. This paper presents the most extensive dataset of high-alpine rockfall to date and the first systematic documentation of a cirquewide erosion response of glaciated rockwalls to recent climate warming.

\section{Introduction}

High-alpine, glacial environments are severely affected by recent climate warming (WGMS, 2017). This is especially true for the European Alps, where mean temperature rise over the last 150 years more than doubled the global mean (Böhm, 2012) and over this period approximately $50 \%$ of the glacier volume has disappeared (Haeberli et al., 2007). Glacier retreat rates increased since the 1980s and have been exceeding historical precedents in the early 21st century (Zemp et al., 2015). The consequences of these changes are most visible in lower lying glacierized cirques where ice-surface lowering in the ablation 
https://doi.org/10.5194/esurf-2020-8

Preprint. Discussion started: 9 March 2020

(C) Author(s) 2020. CC BY 4.0 License.

area is particularly apparent (Kaser et al., 2006; Pelto, 2010) and exposes cirque walls to the atmosphere for the first time in many millennia (Hormes et al., 2001).

Rockwall characteristics strongly depend on preconditioning stress fields (Krautblatter and Moore, 2014). Especially parameters such as fracture density and orientation are first order controls on rock slope erosion (Sass, 2005; Moore et al.,

2009). Glacial oversteepening increases the stress regime acting within cirque walls and promotes rock slope failures at various scales (Ballantyne, 2002; de Haas et al., 2015). Ice surface lowering alters ground thermal conditions (Wegmann et al., 1998) modifies pre-existing slope stresses (Augustinus, 1995; Leith et al., 2014) and therefore potentially causes local instability and elevated mass wasting activity. This has significant implications for risk management in high-alpine environments - especially when considering the growing popularity of glacier tourism (Fischer et al., 2011a; Purdie, 2013). Glacial oversteepening of the surrounding rockwalls and the low friction on the glacier surface often results in long rockfall runouts underneath cirque walls (Schober et al., 2012) putting nearby infrastructure at risk. Continued climate warming is expected to exacerbate this issue, making long-term rockwall monitoring an essential prerequisite for rockfall risk assessment in glacial environments (Stoffel and Huggel, 2012).

Frost action is considered a key agent in preparing and triggering high-alpine rockfall (Draebing and Krautblatter, 2019) and

45 a major driver of rock slope erosion in cold environments (e.g. Hales and Roering, 2009). Only recently a number of studies demonstrated cirque wall retreat rates exceeding rates of glacial incision, underlining the contribution of frost weathering to the shaping of 'glacial' landscapes (Oskin and Burbank, 2005; Naylor and Gabet, 2007; Scherler et al, 2011). Frost weathering processes encompass volumetric ice expansion and ice segregation which are theoretically able to produce pressures exceeding the tensile strength of rocks (Matsuoka and Murton, 2008; Hallet et al., 1991). Volumetric expansion results from freezing of

50 in-situ water and requires high water saturation and extreme cooling rates (Walder and Hallet, 1986; Matsuoka and Murton, 2008). Ice segregation causes cryosuction-induced migration of unfrozen water toward freezing fronts (Walder and Hallet, 1985) and is effective in hard, low-porosity rock at a wide range of sustained sub-zero temperatures (Girard et al., 2013; Duca et al., 2014; Murton et al., 2016). Recent lab studies highlight the importance of fatigue damage under different frost weathering regimes and in different rock types and indicate that subcritical crack propagation plays a key role in the generation of rockfalls

55 in periglacial environments (Jia et al., 2015; Jia et al., 2017).

Rockfall or rock slope failures that are spatiotemporally related to the transition from glacial conditions to non-glacial conditions have been termed 'paraglacial' (McColl, 2012). The paraglacial concept incorporates processes, materials and landforms that are directly conditioned by former glaciation and deglaciation (Church and Ryder, 1972; Ballantyne, 2002). Studies on paraglacial rock slope readjustment often focus on enhanced rates of geomorphic activity after/during deglaciation

60 mainly on rare high-magnitude slope failures. Frequent low-magnitude failure patterns have received comparably little attention. Numerous studies on paraglacial bedrock erosion have focused on Late Pleistocene to Holocene timescales that relate to glacier retreat from Last Glacial maximum (LGM) positions. Relevant studies include extensive mapping of slope instabilities (Allen et al., 2010), terrestrial cosmogenic nuclide dating of post-glacial rock slope failures (Cossart et al. 2008, 
https://doi.org/10.5194/esurf-2020-8

Preprint. Discussion started: 9 March 2020

(C) Author(s) 2020. CC BY 4.0 License.

Ballantyne et al., 2014), effects of glacial debuttressing (McColl and Davies, 2012) and numerical modelling of fracture initiation and propagation during glacial (un)loading (Grämiger et al., 2017).

On a more recent time scale the effects of glacier shrinkage from Little Ice Age (LIA) limits and increased mass wasting activity are unravelled using field mapping (Deline, 2009), photograph comparisons (Ravanel and Deline, 2010), GIS analyses (Holm et al., 2004) and historical documentation (Noetzli et al., 2003). Paraglacial adjustment to the most recent episode of glacial recession - i.e. the dramatic glacier retreat observed over the past few decades - has so far only marginally been addressed. In the Alps, singular, high-magnitude events were examined in the Mont Blanc Massif, France (Deline et al., 2008), at the Piz Kesch, Switzerland (Phillips et al., 2017) and adjacent to the Aletsch Glacier, Switzerland (Manconi et al., 2018) and have at least partially been attributed to current glacier melting. Quantitative studies of lower magnitude paraglacial rockfalls are rare and include a detailed topographic study of rock and ice avalanches in the Monte Rosa east-face, Italy (Fischer et al. 2011b), a four-year time series on a paragneiss ridge at the Gemsstock ski area, Switzerland (Kenner et al., 2011), a two-

75 year monitoring from the Tour Ronde east-face, France (Rabatel et al., 2008), and slope stability surveys from the surroundings of the Refuge des Cosmiques, France (Ravanel et al., 2013).

Quantification of paraglacial rockfall release over larger surfaces and over several years is missing - in large parts due to the harsh, high-alpine environmental conditions - and effectively hinders evaluating the impacts of current glacier retreat on rockfall occurrence. Using data from a six-year terrestrial LiDAR monitoring campaign (2011-2017), we present a rockfall

80 inventory from the Central Alps of Austria that is unique for high-alpine study areas in spatial and temporal extent, and level of detail. We (i) systematically quantify rockfall in two neighbouring, glacial cirques, (ii) reveal significantly increased (paraglacial) rockfall in recently deglaciated rockwall sections immediately above the current glacier surface, and (iii) identify antecedent rockfall preparation inside the Randkluft (subcritical crack propagation, plucking-related tensile stress) and subsequent deglaciation-induced thermal forcing as most likely causes for the observed glacier-proximal concentration of rockfall source areas.

Here, after documenting study area and method applied, an inventory of mass movements is presented. Data quality is analysed, spatial patterns of rockfall and rockfall failure depth are presented and causes of the observed rockfall patterns discussed. Magnitude-frequency relationships and rockwall retreat rates derived from this data are discussed in a companion study (Hartmeyer et al., submitted).

\section{Study Area}

Two cirques located in the summit region of the Kitzsteinhorn (3,203 m a.s.1.), Hohe Tauern Range, Austria (Fig. 1) immediately northwest of the summit were selected for monitoring. Both cirques are occupied by the Schmiedingerkees glacier, which is home to Austria's oldest glacier ski-area. Since 2010 an extensive, multi-scale monitoring of permafrostrockfall interaction ('Open-Air-Lab Kitzsteinhorn') (Keuschnig et al., 2015) includes several deep and shallow boreholes (Hartmeyer et al., 2012), two permanently installed electrical resistivity tomography profiles (Supper et al., 2014; Keuschnig 
https://doi.org/10.5194/esurf-2020-8

Preprint. Discussion started: 9 March 2020

(C) Author(s) 2020. CC BY 4.0 License.

et al., 2016), rock anchor load loggers (Plaesken et al., 2017), extensometers in fractures (Ewald et al., 2019) and several fully automated weather stations.

All rockwalls investigated here tower above the Schmiedingerkees glacier: the Kitzsteinhorn north-face (KN), the Kitzsteinhorn northwest-face (KNW), the Magnetkoepfl east-face (MKE), the Magnetkoepfl west-face (MKW) and the

100 Maurergrat east-face (MGE). The total surface area of all rockwalls studied is $234,700 \mathrm{~m}^{2}$ and with an area of $133,400 \mathrm{~m}^{2}$ and a mean height of roughly $200 \mathrm{~m} \mathrm{KNW}$ is the largest rockwall studied. Slope gradients within and across the rockwalls vary greatly. Typically, gradients increase towards the glacier surface, as is characteristic for cirque walls worldwide (Sanders et al. 2012). With $72^{\circ}$ the steepest mean gradient occurs at MKE, followed by MKW (63), and KNW displays the lowest gradient $\left(44^{\circ}\right)($ Table 1 and Table $\mathrm{S} 1)$.

Table 1: Selected morphometric parameters for all five investigated rockwalls.

\begin{tabular}{lrrrrr} 
& Area & $\begin{array}{r}\text { Altitude } \\
(\mathbf{m i n} / \mathbf{m a x}) \\
(m \text { a.s.l. })\end{array}$ & $\begin{array}{r}\text { Avg. Height } \\
(m)\end{array}$ & $\begin{array}{r}\text { Avg. Slope } \\
\left(m^{2}\right)\end{array}$ & $\begin{array}{r}\text { Avg. } \\
\text { Aspect } \\
\left({ }^{\circ}\right)\end{array}$ \\
\hline Kitzsteinhorn north-face (KN) & 23,500 & $2,921 / 3,060$ & $\sim 70$ & 47 & $(\mathrm{~N}) 357$ \\
Kitzsteinhorn northwest-face (KNW) & 133,400 & $2,768 / 3,203$ & $\sim 200$ & 44 & $(\mathrm{NW}) 322$ \\
Magnetkoepfl east-face (MKE) & 11,100 & $2,853 / 2,953$ & $\sim 55$ & 71 & $(\mathrm{E}) 110$ \\
Magnetkoepfl west-face (MKW) & 6,300 & $2,876 / 2,944$ & $\sim 35$ & 63 & $(\mathrm{~W}) 268$ \\
Maurergrat east-face (MGE) & 60,400 & $2,742 / 2,994$ & $\sim 55$ & 61 & $(\mathrm{E}) 86$ \\
\hline
\end{tabular}

The investigated rockwalls developed in rocks of the Glockner Nappe, mainly calcareous micaschists with isolated occurrences of marble and serpentinite especially at the Magnetkoepfl (Cornelius and Clar, 1935; Hoeck et al., 1994). Cleavage orientation in the predominant calcareous micaschists is similar at all rockwalls studied and dips steeply $\left(\sim 45^{\circ}\right)$ to NNE. Numerous pronounced joint-sets indicate high degrees of fracturing, which is particularly evident along existing tectonic faults (e.g. at

$110 \mathrm{KNW}$ ) and along distinct cleavage planes (e.g. at KN, MKE). Investigations of rock mass strength carried out in all investigated rockwalls indicate highly variable lithologic strength due to the high spatial variability in fracture density (Terweh, 2012).

The Schmiedingerkees glacier has retreated considerably in recent decades and ice-faces have degraded significantly in the surrounding cirque walls (Fig. 1 and Fig. 2). The oldest useable aerial photos date back to 1953 (Land Salzburg, 1953) and demonstrate a glacier area of $3.2 \mathrm{~km}^{2}$. Since then the Schmiedingerkees glacier lost more than half of its size (-56 \%) and the

115 glaciated area decreased to $1.4 \mathrm{~km}^{2}$ (2017). In 2008 the first comprehensive terrain data was acquired for the Schmiedingerkees (Land Salzburg, 2008) using airborne laserscanning. The comparison with current UAV-derived terrain data demonstrates that in the period between 2008 and 2017 glacier volume decreased by 9.8 million $\mathrm{m}^{3}$. Mass loss was most pronounced near the terminus, but also in the root zone, i.e. adjacent to the rockwalls in focus here. Distinct ice-face degradation and glacier retreat is evident with annual surface lowering rates of around $0.5 \mathrm{~m}$ that exposed large, fresh bedrock surfaces (Fig. 1).

120 According to a recent empirical-statistical model of permafrost distribution for the Hohe Tauern range permafrost can be expected above 2,500 m a.s.l. on north-facing slopes and above 3,000 m a.s.l. on south-facing slopes (Schrott et al., 2012). In the study area, permafrost temperatures are monitored since December 2015, in two 30 m deep boreholes located at the northand west-face of the Kitzsteinhorn, at approximately 3,000 m a.s.1.. Bedrock temperatures below the zero annual amplitude 
https://doi.org/10.5194/esurf-2020-8

Preprint. Discussion started: 9 March 2020

(c) Author(s) 2020. CC BY 4.0 License.

are $-1.8{ }^{\circ} \mathrm{C}$ and $-1.3{ }^{\circ} \mathrm{C}$ at the north- and west-face, respectively. Maximum active layer thickness usually occurs in early

125 September and at the north-face increased in thickness from $3.0 \mathrm{~m}$ in 2016, to $3.7 \mathrm{~m}$ in 2017, and $3.9 \mathrm{~m}$ in 2018.

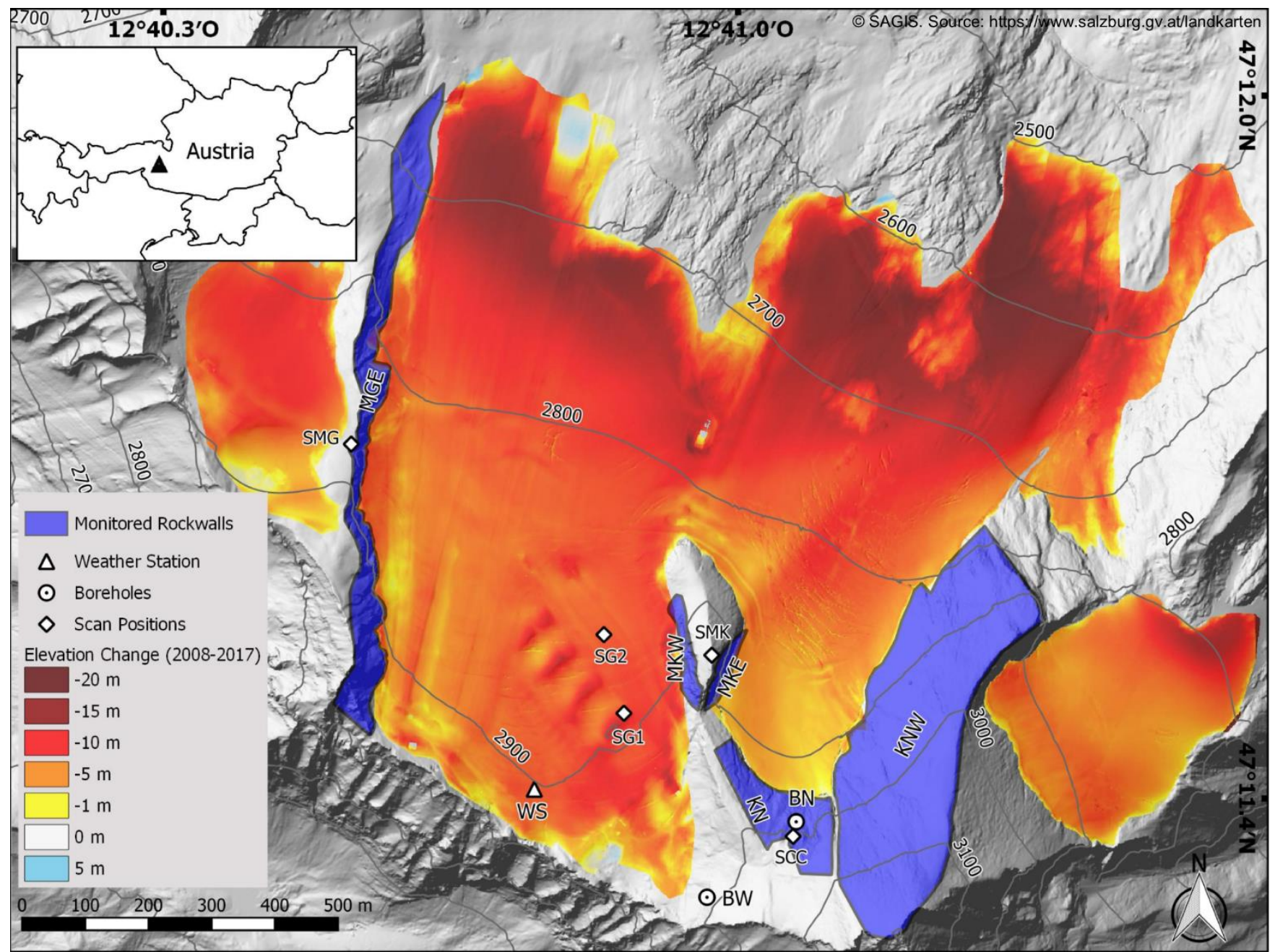

Figure 1: Hillshade of study area with monitored rockwalls, scan positions and elevation changes of the surface of the Schmiedingerkees glacier between 2008 and 2017. While glacial thinning is most evident near the terminus, pronounced ice surface lowering ( $0.5 \mathrm{~m} \mathrm{a-1})$ is also observed adjacent to the monitored cirque walls. Elevation changes were calculated based on comparison between airborne laserscanning data (2008) and UAV-derived photogrammetric data (2017). Inset (top left) shows location of study site within Austria. Abbreviations: K = Kitzsteinhorn (Summit), SMK = Scan Position 'Magnetkoepfl', SCC = Scan Position 'Cable Car Top Station', SG1 = Scan Position 'Glacier 1', SG2 = Scan Position 'Glacier 2', SMG = Scan Position 'Maurergrat', BN = Permafrost Borehole North-Face (30 m), BW = Permafrost Borehole West-Face (30 m), (for other abbreviations see text). 

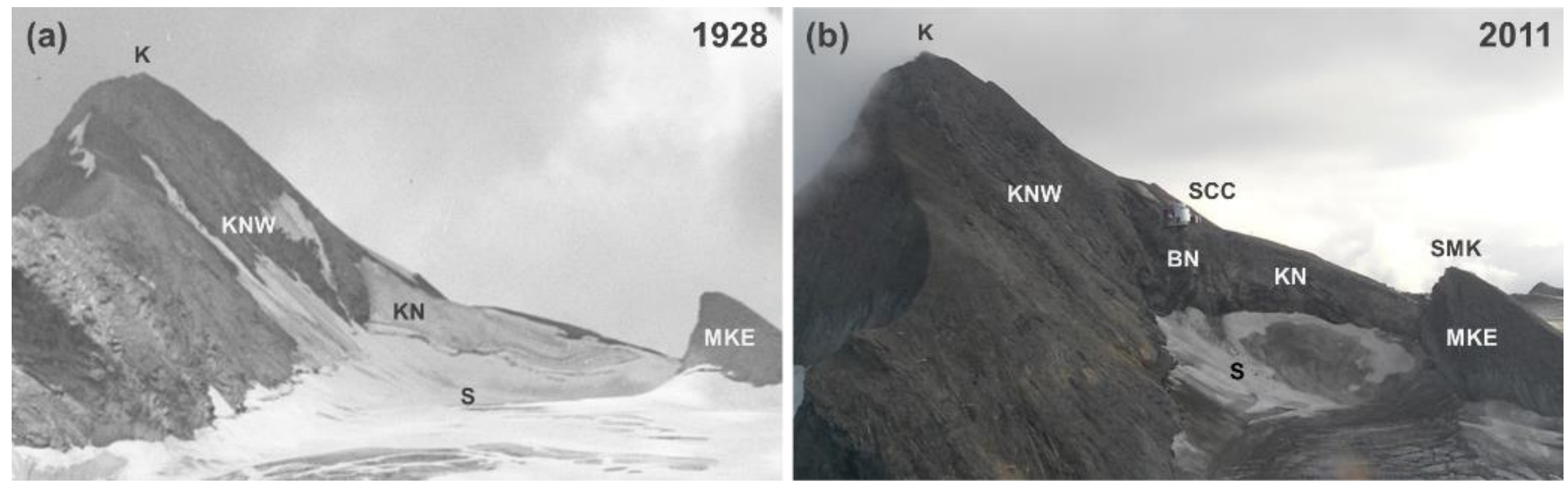

Figure 2: View of Kitzsteinhorn (K) (3.203 m a.s.l.) and Schmiedingerkees glacier (S) from (a) September 1928 (Photo: Stadtarchiv Salzburg, Fotosammlung Josef Kettenhuemer) and (b) September 2011 (Photo: Heinz Kugler). During the reference period the ice surface has lowered considerably while all ice-faces have completely disappeared. Much of the surface change has occurred since the 1980s. Abbreviations: BN = Borehole North-Face, SCC = Scan Position 'Cable Car Top Station', SMK $=$ Scan Position 'Magnetkoepfl' (for other abbreviations see text).

\section{Methods}

\subsection{Data Acquisition}

Terrestrial LiDAR data acquisition was performed using a Riegl LMS-Z620i laserscanner (Table 1). A calibrated highresolution digital camera was mounted on the laserscanner for capturing referenced colour images. Reflectivity on bedrock surfaces was excellent in the near-infrared wavelength used by the scanner, while reflectivity on fresh snow or ice was poor and returned little or no data. Reflectors were not used during data acquisition due to considerable rockfall hazard in the steep, unstable rockwalls.

First LiDAR data was acquired in July/August 2011 at all monitored rockwalls except MKW where data acquisition started in 2012. Data acquisition was restricted to the summer season (May to October). Access to all scan positions required ropes and mountaineering gear, except at the Cable Car Top Station. In total 78 rockwall scans were carried out from five different scan positions. Of these 22 scans were excluded from further analyses due to snow cover. Scan position 'Maurergrat' was abandoned in 2016, as due to continued glacial thinning site access was lost. Rockwall scans were repeated several times per summer season and at least once per season towards the end of the ablation period. The last scan of all rockwalls was carried out in August 2017, except for MKW that was excluded from further analysis, as unstable blocks were cleared away earlier in 2017 to reduce hazards for a new lift track.

The mean object distances (i.e. distance between scanner and rockwall) differed considerably, varying between $140 \mathrm{~m}$ for MKW and $650 \mathrm{~m}$ for MGE. The resulting spatial resolution typically ranged between 0.1-0.3 m (see Table S2 for full list of data acquisition parameters). 
https://doi.org/10.5194/esurf-2020-8

Preprint. Discussion started: 9 March 2020

(C) Author(s) 2020. CC BY 4.0 License.

Table 2: Properties of the Riegl LMS-Z620i terrestrial laserscanner used for this study.

\begin{tabular}{lr}
\hline & Riegl LMS-Z620i \\
\hline Range $(\mathrm{m})$ & up to 2,000 \\
Accuracy $(\mathrm{mm})$ & $10(=1 \sigma$ @ $100 \mathrm{~m})$ \\
Measurement rate $(\mathrm{pts} / \mathrm{sec})$ & up to 11,000 \\
Field of view $\left(^{\circ}\right)$ & $360 \times 80$ \\
Wavelength & near infrared \\
Beam divergence $(\mathrm{mrad})$ & 0.15 \\
Beam footprint at $100 \mathrm{~m}(\mathrm{~mm})$ & 15 \\
Min. angular step width $\left(^{\circ}\right)$ & 0.004 \\
Referenced images & yes \\
\hline
\end{tabular}

\subsection{Data Analysis}

Airborne LiDAR datasets acquired in 2008 (Land Salzburg, 2008) were used as base data for georeferencing. Alignment of the acquired sequential point clouds was performed based on surface geometry matching within RiScanPro 1.8. First, point clouds were coarsely registered using the GPS location of the scan position and the azimuth angle of the laserscanner. Numerous techniques exist for the fine registration of point clouds, which include the Iterative-Closest-Point (ICP) algorithm (Chen and Medioni, 1992; Besl and McKay, 1992), 3D Least Squares Matching (Akca, 2007), point-to-plane approaches (Grant et al., 2012) and others. Here we used the ICP-algorithm, a popular cloud matching technique for finding the transformation between two point clouds by minimizing the square errors between corresponding entities. Consistent with previous studies on rock slope systems (Rosser et al., 2007; Abellán et al., 2011), alignment errors were negligible and typically ranged between 1 and $2 \mathrm{~cm}$.

170 The two most prominent approaches to identify surface changes in successive point clouds include the identification of homologous objects to calculate displacement fields (Teza et al., 2007; Monserrat and Crosetto, 2008) and direct distance calculation (Rosser et al., 2005). Here, the latter type was applied using the M3C2 algorithm which was specifically designed for orthogonal distance measurement in complex terrain (Lague et al., 2013). During the analysis, surface normal orientation is measured at a scale consistent with the local surface roughness and mean surface change is calculated along the normal direction.

The M3C2 algorithm has the benefits of: (i) operating directly on point clouds without the need for meshing or gridding, and thus reduces uncertainties; (ii) computing local distances between point clouds along the surface normal direction, which specifically account for terrain roughness; (iii) providing confidence intervals for all distance measurements and thus allowing to assess the significance of surface changes determined; and (iv) providing robust measures on irregular surfaces and with

180 irregularly-spaced data which is important when comparing point clouds of variable resolutions.

Volumes of detached rock were derived from the distance calculations by identifying source areas, creating local grids and by subsequent grid-cell aggregation. Uncertainties in distance data were propagated using Gaussian error propagation to compute overall uncertainties. In addition, following parameters were determined for each source area: mean slope aspect and gradient, elevation above glacier surface as well as maximum depth of rock detachment (determined as the maximum Euclidean nearest-

185 neighbour distance between the pre-event and the post-event point cloud). Source areas were differentiated as bedrock 
(rockwall) or unconsolidated sediments (intra-rockwall sediment deposits) based on shape, inclination and image colour values. Long return periods between surveys increase the chance of superimposition and coalescence effects, i.e. adjacent or subsequent events are sampled as one failure only (van Veen et al., 2017; Williams et al., 2018). To improve readability 'rockfall source areas' are referred to as 'rockfalls'.

\section{Results}

\subsection{Data Quality}

To investigate the level of confidence that can be given to the scan results, instrumental and referencing uncertainties were quantified, assumed to be normally distributed, propagated using Gaussian error law and are given at one sigma level. The mean relative error associated with rockfall volumes is $0.1 \%$. Relative errors are smaller for large rockfall volumes than for small volumes closer to detection limits. Uncertainty for rockfalls smaller than $1 \mathrm{~m}^{3}$ is $0.8 \%$, while for large rockfalls over $100 \mathrm{~m}^{3}$ relative errors drop to $0.01 \%$ (see Table S3).

The resulting resolution varies between different scans and theoretically leads to the detection of a larger number of small rockfalls in high-resolution scans than in low-resolution scans. This correlation is problematic when scans with different resolutions are compared. To constrain this influence the mean resulting resolution is compared to the normalized number of rockfalls detected, which suggests a weak correlation $\left(\mathrm{R}^{2}=0.18\right)\left(\right.$ Fig. 3). For rockfalls larger than $0.1 \mathrm{~m}^{3}$ the number of rockfalls is independent of resolution and further analyses was limited to this size class. This level of detection is less precise than related LiDAR-based change detection surveys relying on shorter object distances and higher point densities (e.g. Rosser et al., 2007; Williams et al., 2018) but is in good agreement with similar monitoring campaigns carried out in high-alpine settings (e.g. Strunden et al., 2015).

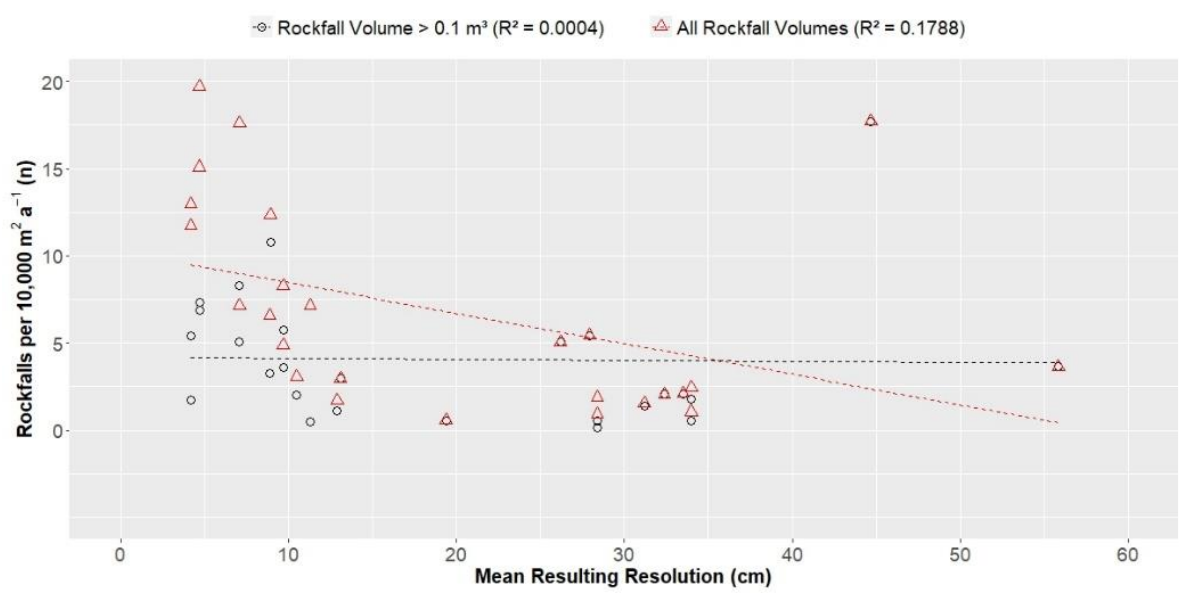

Figure 3: Detected number of rockfalls per $10,000 \mathrm{~m}^{2} \mathrm{a}^{-1}$ plotted against scan resolution. Varying resolutions between acquired scans do not bias the detection of rockfalls larger than $0.1 \mathrm{~m}^{3}$. 
https://doi.org/10.5194/esurf-2020-8

Preprint. Discussion started: 9 March 2020

\subsection{Inventory of Mass Movements}

During the six-year monitoring period (2011-2017) 632 rockfalls were registered with a total volume of 2,564.3 $\pm 1.5 \mathrm{~m}^{3}$.

210 When omitting rockfalls below the threshold of $0.1 \mathrm{~m}^{3}$ (Sect. 4.1), the total number drops to 374, while the overall volume is reduced only marginally to $2,551.4 \pm 1.3 \mathrm{~m}^{3}$ (Table 3 ).

Table 3: Number and volume of registered rockfalls $\left(>0.1 \mathrm{~m}^{3}\right)$.

\begin{tabular}{|c|c|c|c|c|c|c|c|}
\hline & & TOTAL & $\mathrm{KN}$ & KNW & MKE & MKW & MGE \\
\hline \multirow{2}{*}{$0.1-1 \mathrm{~m}^{3}$} & Number (n) & 299 & 83 & 150 & 15 & 8 & 43 \\
\hline & Volume $\left(\mathrm{m}^{3}\right)$ & 94.7 & 24.5 & 45.9 & 6.7 & 2.8 & 14.8 \\
\hline \multirow{2}{*}{$1-10 \mathrm{~m}^{3}$} & Number (n) & 50 & 13 & 21 & 4 & 5 & 7 \\
\hline & Volume $\left(\mathrm{m}^{3}\right)$ & 151.8 & 48.3 & 65.9 & 12.6 & 10.7 & 14.4 \\
\hline \multirow{2}{*}{$10-100 \mathrm{~m}^{3}$} & Number (n) & 20 & 5 & 7 & 3 & 2 & 3 \\
\hline & Volume $\left(\mathrm{m}^{3}\right)$ & 547.8 & 104.6 & 156.7 & 54.0 & 136.2 & 96.4 \\
\hline \multirow{2}{*}{$100-1,000 \mathrm{~m}^{3}$} & Number (n) & 5 & 3 & 1 & 1 & - & - \\
\hline & Volume $\left(\mathrm{m}^{3}\right)$ & 1757.0 & 1278.0 & 272.7 & 206.3 & - & - \\
\hline \multirow{2}{*}{ All Rockfalls } & Number (n) & 374 & 104 & 179 & 23 & 15 & 53 \\
\hline & Volume $\left(\mathrm{m}^{3}\right)$ & $2,551.4$ & $1,455.4$ & 541.2 & 279.6 & 149.7 & 125.5 \\
\hline
\end{tabular}

Large rockfalls over $100 \mathrm{~m}^{3}$ are rare $(\mathrm{n}=5)$ but account for more than two thirds $(68.5 \%)$ of the total volume. The largest registered rockfall has a volume of $879.4 \mathrm{~m}^{3}$, the volumes of the three next largest rockfalls range between $200-300 \mathrm{~m}^{3}$. With increasing volume an exponential decrease in number of rockfalls can be observed. Small rockfalls below $1 \mathrm{~m}^{3}$ represent 80 $\%$ of the total number but account for only $3.7 \%$ of the overall rockfall volume (see companion study (Hartmeyer et al., submitted) for detailed discussion of magnitude-frequency distributions).

Frontal photographs of the monitored rockwalls are provided in Fig. 4. The source areas and rockfall volumes $\left(>0.1 \mathrm{~m}^{3}\right)$ indicate that pre-existing weaknesses exert a strong control on rockfall occurrence. Concentration of rockfalls around fracture systems is particularly evident at $\mathrm{KN}$ (along cleavage planes) and $\mathrm{KNW}$ (along a prominent fault across the entire rockwall). The highest number of rockfalls was found at the largest rockwall KNW $(n=179)$. Lowest rockfall numbers were recorded at the smallest rockwalls at Magnetkoepfl (MKE, MKW) (Table 1). By far the highest total rockfall volume $\left(1,455.4 \pm 0.2 \mathrm{~m}^{3}\right)$ was found at $\mathrm{KN}$ despite its relatively small size. Three of the five largest rockfalls occurred here. The second highest total volume was detected at $\mathrm{KNW}\left(541.2 \pm 0.6 \mathrm{~m}^{3}\right)$, while the lowest volume was recorded at MGE $\left(125.5 \pm 0.2 \mathrm{~m}^{3}\right)$.

225 In addition to rockfalls, 113 source areas of slide-, creep- or debris-flow-like mass movements were identified in unconsolidated sediments. The total volume of these mass movements is $292.0 \pm 0.4 \mathrm{~m}^{3}$. Nine mass movements larger than 10 $\mathrm{m}^{3}$ were identified and account for $56.2 \%$ of the total volume. The size distribution follows the pattern of rockfall volume distribution where smaller mass movements are frequent but represented only a small part of the overall volume and show an exponential decrease in number with increasing volume (Table S4). These types of mass movement were almost fully limited to KNW and KN. The two rockwalls are the least steep and permit accumulation of thin sediment veneers on intra-rockwall couloirs and ledges. Together, KNW and KN display $90.3 \%$ of the total number and $99.3 \%$ of the total volume of all loose sediment movements. 
https://doi.org/10.5194/esurf-2020-8

Preprint. Discussion started: 9 March 2020

(C) Author(s) 2020. CC BY 4.0 License.

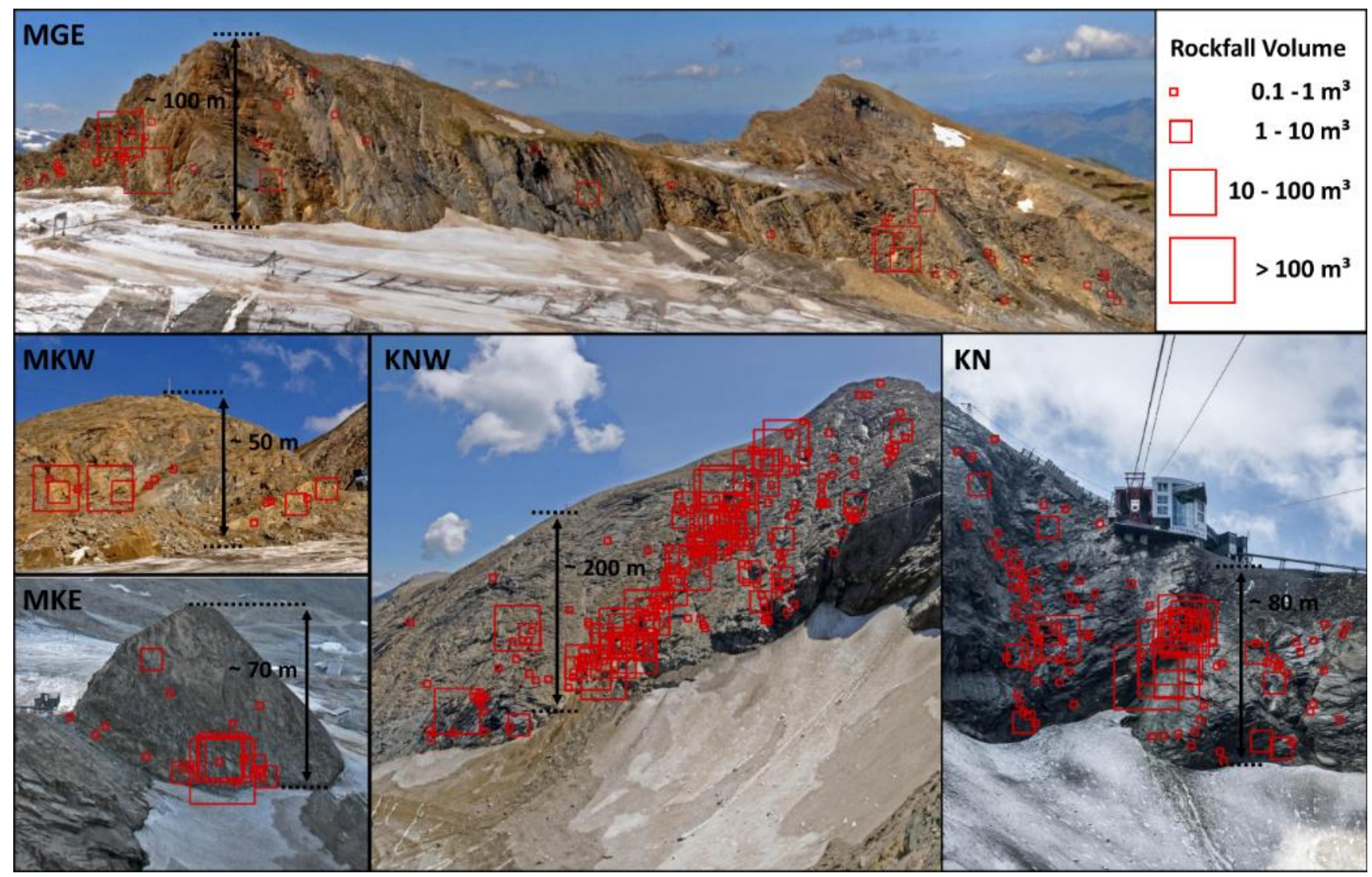

Figure 4: Rockfall source areas and volumes for all five monitored rockwalls. A clear linear distribution along major joint intersections is evident at all rockwalls and is particularly apparent at KNW (Kitzsteinhorn northwest-face) and KN (Kitzsteinhorn north-face) (Photos: Robert Delleske).

Further mass losses identified relate to ice-face degradation in four well-shaded locations at the lower part of KN adjacent to the glacier surface. The overall ice loss from 2011-2017 was 575.9 $\pm 0.04 \mathrm{~m}^{3}$. The single biggest recorded ice loss was 424.1 $\mathrm{m}^{3}$ between August 2012 and August 2015 (no data acquisition in 2013 and 2014 due to persistent snow cover), followed by

240 mass losses of $66.8 \mathrm{~m}^{3}$ and $51.4 \mathrm{~m}^{3}$ between August 2016 and August 2017, and a mass loss of $33.6 \mathrm{~m}^{3}$ between August 2015 and August 2016. The two mass losses recorded between 2016 and 2017 are underestimated as late snow cover during the second scan obscured the rockwall.

\subsection{Spatial Rockfall Distribution}

The bulk of the registered rockfalls originated in N- and NW-oriented rockwall sections between 2,900 and 3,100 m a.s.1., 245 mostly due to the dominant influence of $\mathrm{KN}$ and $\mathrm{KNW}$ which are both dissected by pronounced weakness zones. East-facing rockfall source areas between 2,800 and 3,000 m a.s.l. represent another distinct azimuth cluster (Fig. 5). 


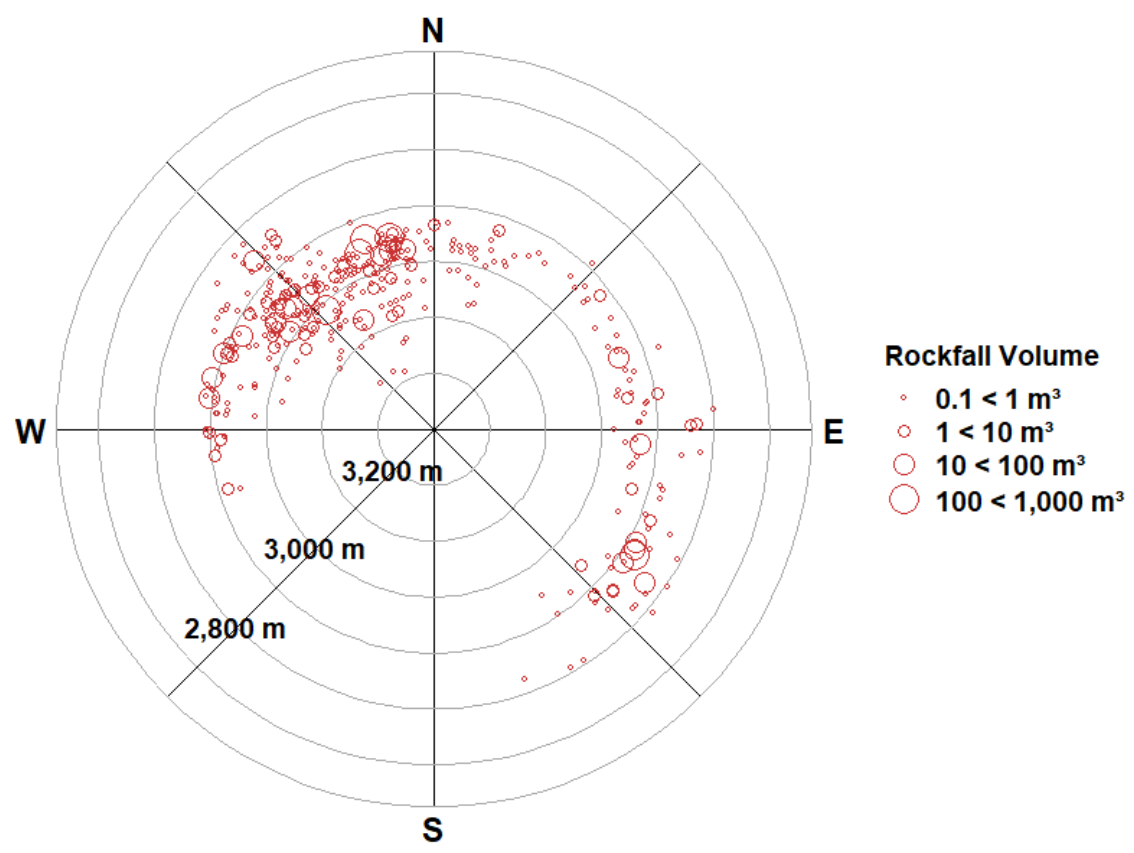

Figure 5: Slope azimuth angle and elevation above sea level for all rockfalls $\left(>0.1 \mathrm{~m}^{3}\right)$. Most rockfalls originated in $\mathrm{N}$ - and $\mathrm{NW}$ oriented rockwall sections reflecting the dominant influence of KN (Kitzsteinhorn north-face) and KNW (Kitzsteinhorn northwestface).

To further explore rockfall distribution with elevation, we classified the investigated surfaces into vertical $50 \mathrm{~m}$ bins. Total rockwall surface area is almost normally distributed and shows the largest share between 2,900-2,950 m a.s.1. ( 65,000 m²; $27.0 \%$ of total surface area) (Fig. 6a and Table S5). Normalized and absolute rockfall volumes peak in the same elevation class. Over $37 \mathrm{~m}^{3}$ per 10,000 $\mathrm{m}^{2}$ a-1 originated between 2,900-2,950 m a.s.l. (Fig. 6b), which is equivalent to more than half

$255(54.4 \%)$ of the total rockfall volume (Table S5).

The normalized number of rockfalls is highest between 2,950-3,000 m a.s.1. (4.6 rockfalls per 10,000 $\mathrm{m}^{2}$ a-1). With increasing/decreasing elevation, normalized rockfall numbers decline significantly, similar to the altitudinal distribution of surface area (Fig. 6c). Absolute rockfall numbers peak between 2,900-2,950 m a.s.1. and 2,950-3,000 m a.s.1., where approximately two thirds $(63.8 \%)$ of the detected rockfalls originate (Table S5).

260 To detail the vertical distribution of rockfall source areas, the elevation differences between rockfall source areas and local glacier surface are calculated and grouped into $10 \mathrm{~m}$ bins (Fig. 7a and Table S1). Immediately above the glacier surface (0-10 m) rockfall volumes are by far the highest $\left(75.6 \mathrm{~m}^{3}\right.$ per $\left.10,000 \mathrm{~m}^{2} \mathrm{a}-1\right)$ (Fig. $\left.7 \mathrm{~b}\right) .60 \%$ of the total rockfall volume detached from this segment, which constitutes only $15 \%$ of the total rockwall surface area. With increasing distance from the glacier surface, a sharp decrease in rockfall volume can be observed. In the next higher segment (10-20 m), normalized rockfall

265 volume slightly exceeds $20 \mathrm{~m}^{3}$ per $10,000 \mathrm{~m}^{2} \mathrm{a}-1$, while in all other height classes rates remain below $10 \mathrm{~m}^{3}$ per $10,000 \mathrm{~m}^{2}$ a1. Only in two segments $(90-100 \mathrm{~m}, 170-180 \mathrm{~m})$, this pattern is masked by the presence of comparatively large, singular rockfalls. 

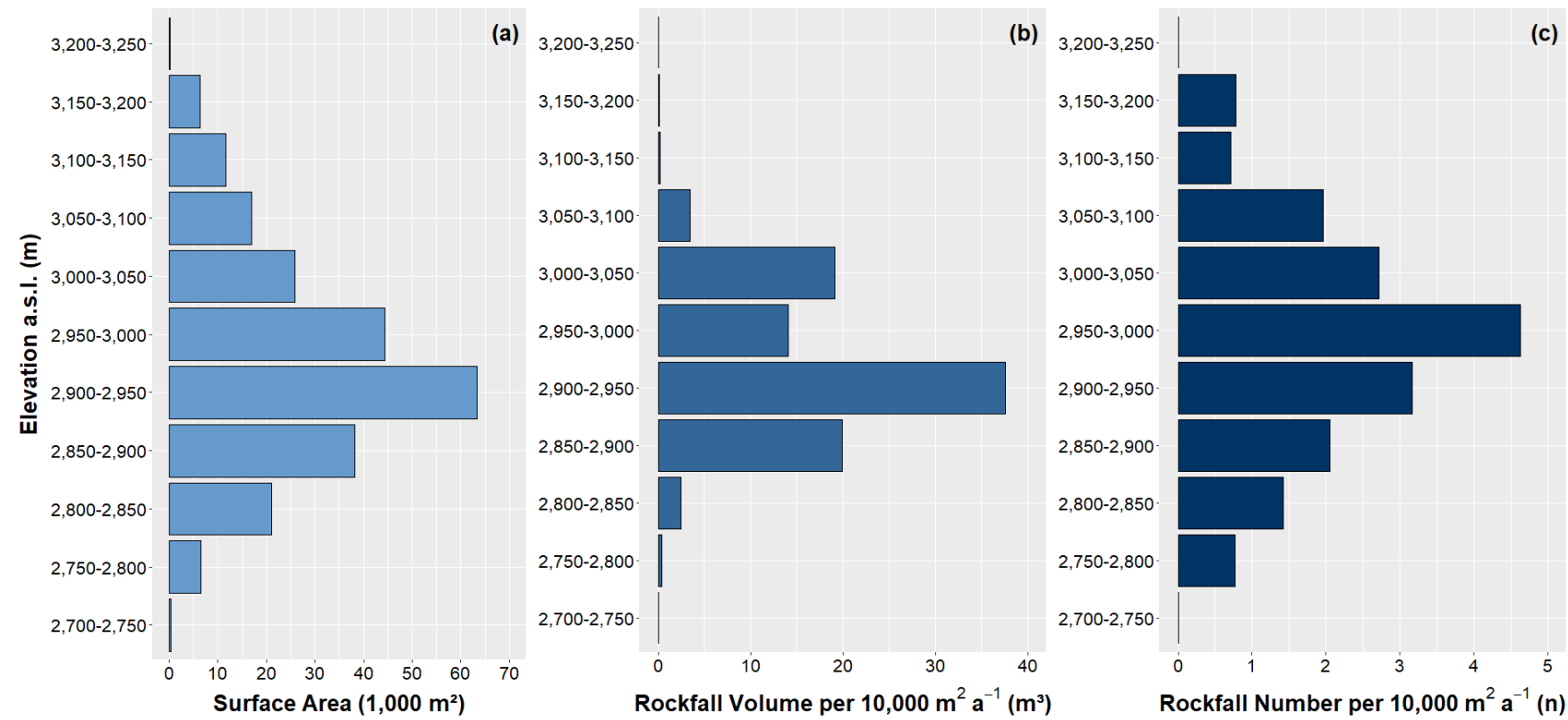

Figure 6: (a) Rockwall surface area, (b) normalized rockfall volume and (c) the normalized number of rockfalls, grouped by elevation above sea level. Between 2,900 and $2,950 \mathrm{~m}$ a.s.l. a distinct peak in rockfall volume is observed.

Analysed individually, a positive correlation between rockfall volume and proximity to glacier surface occurs for all rockwalls except KNW. The vast majority of the rockfall volume is detected within $10 \mathrm{~m}$ of the glacier surface at MGE (73\%), KN (79 $\%)$ and MKE (98\%). Considering the first $20 \mathrm{~m}$ above glacier surface the volume percentages exceed $90 \%$ for all three rockwalls.

275 At MKW rockfall volumes are small in the lowest segment (3\%) and $96 \%$ of the rockfall volume occur in the segment above (10-20 m). Here, a rockfall event from the early 2000s, created a steep scarp around $15 \mathrm{~m}$ above the current glacier surface. The rockfall deposits, likely several thousand cubic meters of rock, accumulated at the foot of MKW and constituted a talus cone that decoupled parts of the rockwall from the glacier. The rockfall scarp remained a prominent source area for rockfall during the monitoring period, indicating continued stress release after the initial event. Rockfall from this scarp was the main reason why this rockwall displays a differing pattern and maximum retreat rate does not occur within the first ten vertical meters above glacier surface.

As mentioned no pronounced glacial proximity pattern was found for $\mathrm{KNW}$, where only $12 \%$ of the rockfall volume detached within the first $10 \mathrm{~m}$. Here, a significant $272.7 \pm 0.03 \mathrm{~m}^{3}$ rockfall occurred in summer 2016 which constituted around half of the total rockfall volume at this site. Its rockfall source area is located $97 \mathrm{~m}$ above the glacier surface and may coincide with the LGM trim line. Still, after excluding this event, only a rather weak proximity pattern is observed ( $23 \%$ of the volume within the lowest $10 \mathrm{~m}$ ) clearly deviating from the patterns observed at the other four rockwalls.

Analysis of rockfall numbers confirms the glacial proximity pattern even though the correlation is much less pronounced than for the elevation volume distribution. Highest normalized rockfall numbers (3.9 rockfalls per 10,000 $\left.\mathrm{m}^{2} \mathrm{a}-1\right)$ are once again 
https://doi.org/10.5194/esurf-2020-8

Preprint. Discussion started: 9 March 2020

(C) Author(s) 2020. CC BY 4.0 License.

found in the lowest segment $(0-10 \mathrm{~m})$ (Fig. 7c). The mean value for all higher segments (i.e. 10-260 m) equals $2.5 \mathrm{rockfalls}$ per $10,000 \mathrm{~m}^{2}$ a-1 with significant variations between the different height classes. Overall $21 \%$ of all rockfalls occurred in the first $10 \mathrm{~m}$ above the glacier surface - a distinct contrast to the dominance of rockfall volumes in that segment.

Comparing rockfall numbers across the rockwalls yields diverse results: At KN particularly high rockfall numbers are found between 30 and $50 \mathrm{~m}$ above the glacier. KNW shows a more uniform pattern with a rather balanced distribution over the first $100 \mathrm{~m}$ and a slight decrease at higher elevations. At MKE, rockfall is restricted to the immediate adjacency to the glacier and above the 0-10m-segment only minimal rockfall activity is observed. At MKW and MGE, most rockfalls occurred within 20 m of the glacier surface $(\sim 70 \%$ and $90 \%$, respectively).
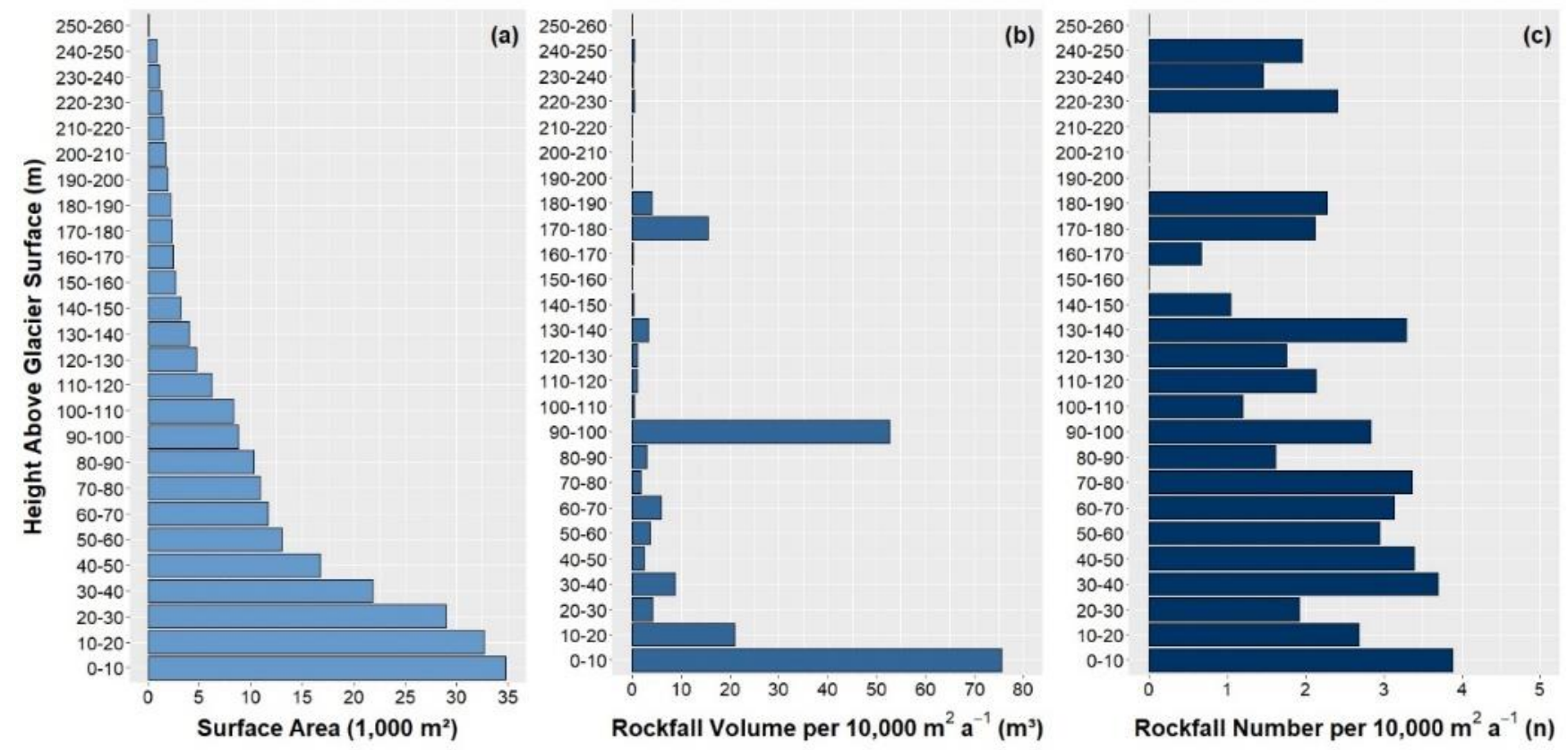

Figure 7: (a) Rockwall surface area, (b) normalized rockfall volume and (c) the normalized number of rockfalls, classified by elevation above glacier surface. Areas exposed by recent glacier retreat are heavily susceptible to rockfall, during the observation period (2011-2017) $60 \%$ of the total rockfall volume detached within $10 \mathrm{~m}$ of the current glacier surface.

\subsection{Rockfall Failure Depths}

To compare rockfall patterns to depth of permafrost thaw, depth of failure was analysed which ranges between 0.17 and 6.45 m. Near-surface failures are dominant as $69 \%$ of all rockfalls failed within the top $0.5 \mathrm{~m}$ and another $22 \%$ had failure depths between 0.5 and $1 \mathrm{~m}$. Eleven rockfalls with failure depths of more than $2.0 \mathrm{~m}$ were recorded $(2.9 \%)$ and only five rockfalls failed in depths larger than $3.0 \mathrm{~m}(1.3 \%)$ (Fig. 8, Table S6). 


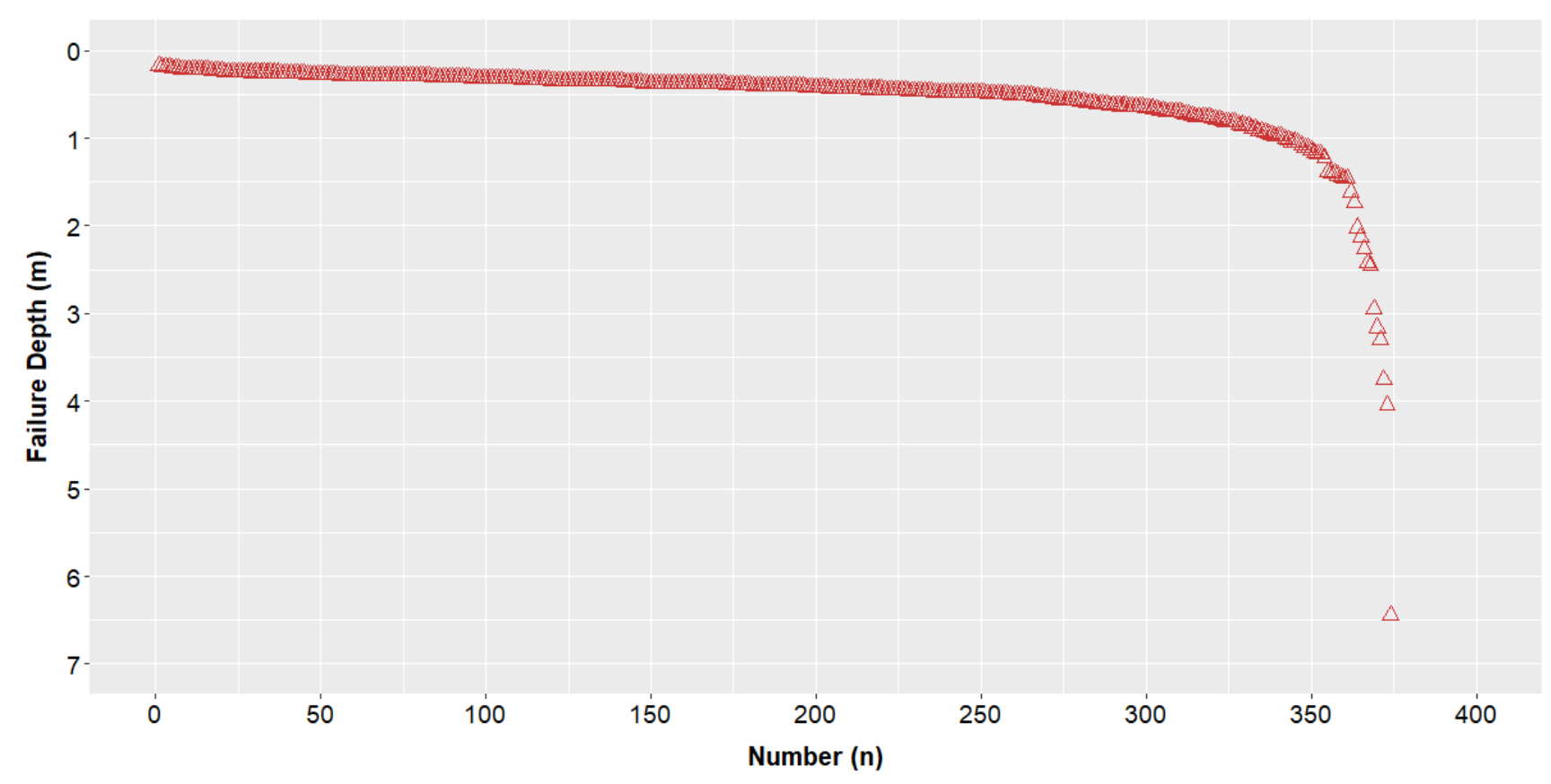

Figure 8: Depth of detachment plane for all registered rockfalls $\left(>0.1 \mathrm{~m}^{3}\right)$. More than $90 \%$ of all rockfalls failed within less than 1 $m$ from the surface.

\section{Discussion}

310 The analysis of long-term terrestrial LiDAR data from two high-alpine cirques shows that rockfall source areas are grouped along heavily fractured, pre-existing structural weaknesses, which is consistent with former studies that found correlations between joint density and rockwall retreat (Sass, 2005; Moore et al., 2009). Further analysis reveals considerably increased rockfall activity in the immediate proximity (10-20 vertical meters) of the current glacier surface, which emerged from the ice only very recently. While some of the increase may be related to a slight steepening of rockwall gradients towards the glacier surface, a number of other processes are likely responsible for the observed glacier-proximal rockfall increase.

\subsection{Antecedent Rockfall Preparation inside the Randkluft}

Slope debuttressing following deglaciation is frequently considered to cause mass movements, particularly in case of larger slope failures. (e.g. Holm et al., 2004; Allen et al., 2010). At the base of the investigated rockwalls, however, seasonally airor snow-filled voids between glacier and cirque wall ('Randkluft') prevent permanent physical contact between rock and ice and thus effectively hinder debuttressing. The existence of a Randkluft is not site-specific but rather common at alpine (cirque) glaciers (e.g. Gardner, 1987; Mair and Kuhn, 1994; Sanders et al., 2012). Among the rockwalls investigated here, Randkluft systems are most pronounced below $\mathrm{KN}$, possibly due to the principal flow direction of the adjacent glacier perpendicularly 
away from the slope. Randkluft development is rather limited at KNW, likely caused by substantial (avalanche) snow accumulation at the foot of the tall, low-gradient rockwall.

325 Local Randkluft systems at the Kitzsteinhorn are usually open during late summer/early fall (Fig. 9), even though Randkluft width and depth exhibit considerable interannual variations. It is evident from our observations that the debuttressing effect, if relevant at all (McColl, 2012; McColl and Davies, 2012), can occur subglacially only, in the lowermost parts of the Randkluft. Sporadically, the collapse of ice bridges may cause small-scale debuttressing locally, but in general this mode of failure seems not too effective. Debuttressing can also not explain the increased rockfall activity several meters above the glacier surface,

330 i.e. in areas already ice-free for years or decades.

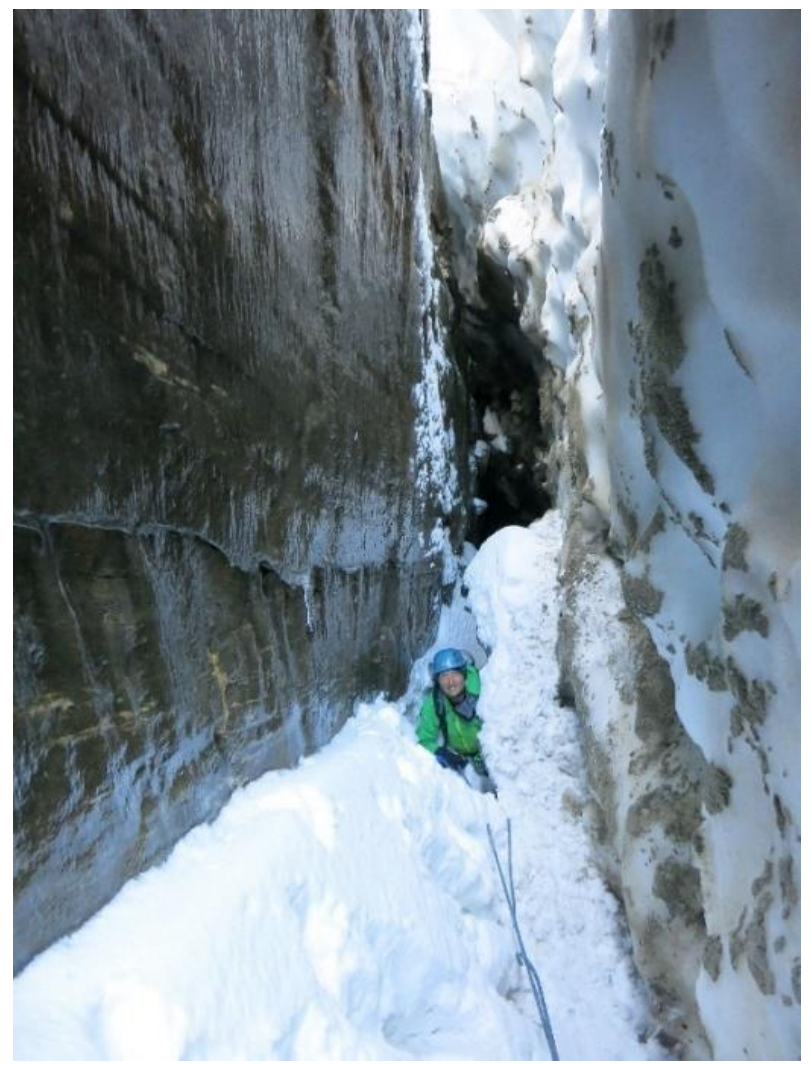

Figure 9: Inside the Randkluft below KN (Kitzsteinhorn north-face). Pictured person is standing approximately $8 \mathrm{~m}$ below the glacier surface. Continuous ice coating (verglas) on the cirque wall (left half of the photo) indicates permanently frozen conditions inside the Randkluft (Photo: Ingo Hartmeyer, 09.10.2015).

335 Previous modelling approaches assume unfrozen conditions for currently glacier-covered, north-facing headwall sections and aggradation of new permafrost after deglaciation (Wegmann et al., 1998). Other studies report distinct permafrost conditions inside Randkluft systems based on in-situ temperature measurements (Sanders et al., 2012). Our observations match with the latter findings, as we encountered rockwalls coated with refrozen meltwater ('verglas') as deep as $15 \mathrm{~m}$ below the glacier surface during late summer (Fig. 9). The existence of perennially frozen conditions inside the Randkluft combined with 
https://doi.org/10.5194/esurf-2020-8

Preprint. Discussion started: 9 March 2020

(c) Author(s) 2020. CC BY 4.0 License.

observed extensive meltwater supply from the rockwall above may significantly contribute to the efficacy of frost weathering in subglacial cirque wall sections. One of the few quantitative studies indicates particularly effective rock-fracturing driven by ice segregation within the Randkluft of a temperate glacier in British Columbia, Canada (Sanders et al., 2012). This observation has recently been substantiated by numerous field and lab experiments demonstrating intense frost cracking at temperatures just below $0{ }^{\circ} \mathrm{C}$ (Girard et al., 2013; Duca et al., 2014; Murton et al., 2016) and thermo-cryogenic rock fatigue due to damage accumulation over longer time scales (Jia et al., 2015). Subcritical stress propagation driven by sustained freezing and sufficient water supply (Jia et al., 2017; Draebing and Krautblatter, 2019), and high plucking-related tensile stresses caused by refreezing meltwater at the bottom of the Randkluft (Lewis, 1938; Hooke, 1991). We hypothesize, therefore, that they are the dominant antecedent processes of rockfall preparation. The special weathering conditions may prepare the high fragmentation of nearRandkluft bedrock which efficiently predisposes cirque walls to shallow failures and ultimately controls the high post-glacial rockfall activity. This idea is further underpinned by a possible positive correlation between Randkluft size and glacierproximal rockfall volume. Highest proximal rockfall volumes are found at KN and MKE which also host the largest Randkluft systems of all rockwalls monitored. Lowest proximal rockfall volumes are recorded at KNW where Randkluft formation is suppressed due to massive local snow accumulation at the glacier fringe.

\subsection{Deglaciation-Induced Thermomechanical Forcing and Active Layer Formation}

355 As glaciers are wasting down, freshly exposed rockwall sections are shifted from subglacial to subaerial boundary conditions. The quantitative effects of this transition are elusive, as direct measurements from subglacial cirque wall sections are rare (Gardner, 1987; Sanders et al., 2012). Yet it is expected that thermal conditions in cirque walls are modified significantly as they emerge from isothermal, subglacial conditions - a transition that has recently been named 'paraglacial thermal shock' (Grämiger et al., 2018). Once ice-free, strong diurnal and seasonal variations are likely to induce pronounced thermal stress leading to deformation (Hasler et al., 2012; Weber et al., 2017) and potentially to failure along critically-stressed discontinuities (Hall, 1999; Gischig et al., 2011). Additionally, cyclic freeze-thaw action will cause rock fatigue (Jia et al., 2015), hydrofracture (Davidson and Nye, 1985; Sass, 2004) and the expansion of water-filled joints (Matsuoka and Murton, 2008), all of which promote destabilization in recently deglaciated rockwall sections (Draebing et al., 2017).

Active layer deepening - a key element of permafrost degradation (Ravanel et al., 2017) - significantly alters rock- and ice-

365 mechanical properties (Davies et al., 2001; Krautblatter et al., 2013) and is frequently considered in high-alpine rockfall analyses (e.g. Gruber and Haeberli, 2007; Weber et al., 2019). Failure depth of rockfalls related to permafrost degradation is expected to equal or exceed maximum active layer thickness. At a local borehole monitoring site at $\mathrm{KN}$ the active layer depth varies between 3-4 m inter-annually. Based on these values, only $0.5 \%$ (below $4 \mathrm{~m}$ ) to $1.3 \%$ (below $3 \mathrm{~m}$ ) of all rockfalls failed at a depth below the maximum seasonal active layer. Volume shares are significantly higher due to the large size of the 370 deeper-seated events: Rockfalls with failure depths larger than $3 \mathrm{~m}(4 \mathrm{~m})$ constitute $44 \%$ (60\%) of the total rockfall volume, suggesting that permafrost degradation could indeed have a substantial impact on total rockfall volume. 
Active layer thickness is expected to vary strongly across the investigated rockwalls (Schrott et al., 2012), mainly due to topography effects (Gruber et al., 2004) and snow cover variations (Haberkorn et al., 2015). Active layer depth monitored at $\mathrm{KN}$ is therefore unlikely to be representative for the entire study area. Particularly for recently deglaciated rockwall sections, permafrost dynamics are poorly understood due to the complex local interplay of glaciological, meteorological and geological controls (Draebing et al., 2014). Observations point at the complete absence of an active layer in glacier-covered rockwall sections (Fig. 9). Glacial downwasting would thus uncover permanently frozen rockwalls and cause the formation of an incipient active layer. This process is expected to have a significant destabilizing effect (Davies et al., 2001; Krautblatter et al., 2013) and may therefore contribute considerably to the increased rockfall activity near the current glacier surface.

380 Further influences that potentially contribute to high glacier-proximal rockfall activity, include late-spring ground avalanches and channelized rainwater runoff after heavy precipitation. Visual observation suggests strong erosive effects for these processes in the freshly deglaciated sections where blocks at failure stability limit are abundant (Fig. 10). More precise quantification of such processes would require significantly shorter survey return periods.

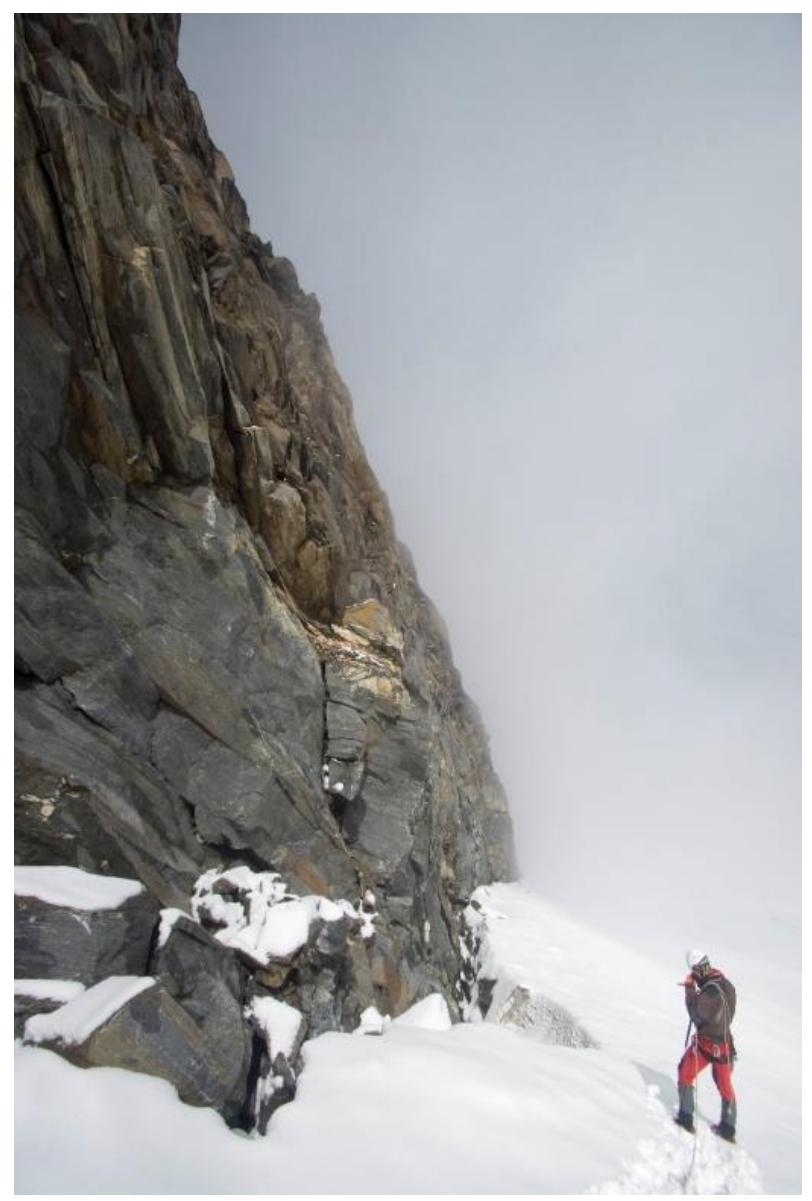

385 Figure 10: Magnetkoepfl east-face (MKE) and adjacent glacier separated by Randkluft. Recently deglaciated, unstable blocks are visible in the first meters above the glacier surface. Occasionally rockfall deposits are wedged between rockwall and Randkluft lip (bottom left) (Photo: Robert Delleske, 04.09.2015). 
https://doi.org/10.5194/esurf-2020-8

Preprint. Discussion started: 9 March 2020

(C) Author(s) 2020. CC BY 4.0 License.

\section{Conclusions}

We present a unique rockfall inventory from a six-year terrestrial LiDAR campaign (2011-2017) for permafrost-affected rockwalls of two glaciated cirques in the Central Alps of Austria (Kitzsteinhorn). The five rockwalls studied are all influenced by significant glacial downwasting and ice-face degradation. We draw the following conclusions:

- The inventory represents the most extensive dataset of high-alpine rockfall to date and the first quantitative documentation of a cirque-wide erosional response of glaciated rockwalls to recent climate warming.

- $\quad$ During the monitoring period 632 rockfalls with an overall volume of 2,564.3 $\pm 1.5 \mathrm{~m}^{3}$ were recorded. In addition, 113 rockfall source areas with a total volume of $292.0 \pm 0.4 \mathrm{~m}^{3}$ were detected in unconsolidated sediments. Mass loss from ice-face degradation accounted for an overall volume of $575.9 \pm 0.04 \mathrm{~m}^{3}$.

- Rockfall activity concentrates along pre-existing structural weaknesses and was highest in recently deglaciated areas: $60 \%$ of the rockfall volume originated from source areas located fewer than ten vertical meters above the current glacier surface; $75 \%$ detached within 20 vertical meters of the glacier surface.

$400 \quad$ - Increased mass wasting activity in recently deglaciated areas, such as discovered in the present study, is typical of paraglacial environments, where slope systems gravitationally adjust to new, non-glacial boundary conditions.

- $\quad$ Previous studies on the paraglacial adjustment of bedrock slopes mostly focused on high-magnitude events such as rock avalanches and rockslides, which commonly respond to deglaciation on centennial to millennial time scales. The lower end of the paraglacial magnitude-frequency spectrum is currently poorly characterized. The present study bridges this gap and for the first time provides field evidence of an immediate, low-magnitude paraglacial response in a currently deglaciating rock slope system.

- Distinct Randklufts, which separate the investigated cirque walls from the adjacent glacial ice, effectively prevent debuttressing. Inside the Randkluft we observed perennially frozen conditions and extensive refreezing of meltwater supplied from the rockwall above.

- $\quad$ Sustained freezing along with sufficient water availability in the Randkluft likely drive subcritical stress propagation and cause high plucking-related tensile stresses, which contribute to antecedent rockfall preparation when the rockwall is still ice-covered.

- $\quad$ As the glacier is wasting down strong diurnal and seasonal temperature variations induce pronounced thermal stress, cause rock fatigue and lead to the first-time formation of an active layer, which is expected to exert a significant destabilizing effect on glacier-proximal areas.

Data availability. The rockfall inventory can be downloaded from the mediaTUM data repository under the following weblink: https://mediatum.ub.tum.de/1540134.

Supplement. The supplement is provided in a separate file. 
https://doi.org/10.5194/esurf-2020-8

Preprint. Discussion started: 9 March 2020

(C) Author(s) 2020. CC BY 4.0 License.

(c) (i)

Author contributions. MKE, LS and JO initiated the underlying research project in 2010 and obtained the funding. MKE, IH and RD developed the idea and designed the study. IH and RD conducted the data acquisition and IH analysed the data. All authors contributed to the discussion and interpretation of the data. IH drafted the manuscript with significant contributions from MKR and AL.

Competing interests. The authors declare that they have no conflict of interest.

Financial support. This study was co-funded by the Austrian Academy of Sciences (ÖAW) (Project 'GlacierRocks'), the

Arbeitsgemeinschaft Alpenländer (ARGE ALP) (Project 'CirqueMonHT') and the Austrian Research Promotion Agency (FFG) (Project 'MOREXPERT'). We furthermore thank the Gletscherbahnen Kaprun AG (Project 'Open-Air-Lab Kitzsteinhorn') for financial and logistical support.

\section{References}

Abellán, A., Vilaplana, J. M., Calvet, J., García-Sellés, D., and Asensio, E.: Rockfall monitoring by Terrestrial Laser Scanning 430 - case study of the basaltic rock face at Castellfollit de la Roca (Catalonia, Spain), NAT HAZARD EARTH SYS, 11(3), 829$841,2011$.

Akca, D.: Least Squares 3D Surface Matching, Ph.D. thesis, Swiss Federal Institute of Technology Zurich, 2007.

Allen, S. K., Cox, S. C., and Owens, I. F.: Rock avalanches and other landslides in the central Southern Alps of New Zealand: a regional study considering possible climate change impacts, LANDSLIDES, 8(1), 33-48, 2010.

435 Augustinus, P. C.: Glacial valley cross-profile development: the influence of in situ rock stress and rock mass strength, with examples from the Southern Alps, New Zealand, GEOMORPHOLOGY, 14(2), 87-97, 1995.

Ballantyne, C. K.: Paraglacial geomorphology, QUATERNARY SCI REV, 21(18-19), 1935-2017, 2002.

Ballantyne, C. K., Sandeman, G. F., Stone, J. O., and Wilson, P.: Rock-slope failure following Late Pleistocene deglaciation on tectonically stable mountainous terrain, QUATERNARY SCI REV, 86, 144-157, 2014.

440 Benn, D. I. and Evans, D. J. A.: Glaciers \& Glaciation, Routledge Taylor \& Francis Group, London and New York, 2010. Besl, P. J. and McKay, N. D.: A method for registration of 3-D shapes, IEEE T PATTERN ANAL, 14(2), $239-256,1992$. Böhm, R.: Changes of regional climate variability in central Europe during the past 250 years, EUR PHYS J PLUS, 127(5), 2012.

Chen, Y. and Medioni, G.: Object modelling by registration of multiple range images, IMAGE VISION COMPUT, 10(3), $445145-155,1992$.

Church, M. and Ryder, J.: Paraglacial Sedimentation: A Consideration of Fluvial Processes Conditioned by Glaciation, GEOL SOC AM BULL, 83(10), 3059, 1972.

Cornelius, H. and Clar, E.: Erläuterungen zur geologischen Karte des Glocknergebietes, Geologische Bundesanstalt, Vienna, 32 pp., 1935. 
https://doi.org/10.5194/esurf-2020-8

Preprint. Discussion started: 9 March 2020

(c) Author(s) 2020. CC BY 4.0 License.

Cossart, E., Braucher, R., Fort, M., Bourlès, D. L., and Carcaillet, J.: Slope instability in relation to glacial debuttressing in alpine areas (Upper Durance catchment, southeastern France): Evidence from field data and 10Be cosmic ray exposure ages, GEOMORPHOLOGY, 95(1-2), 3-26, 2008.

Davidson, G. P. and Nye, J. F.: A photoelastic study of ice pressure in rock cracks, COLD REG SCI TECHNOL, 11(2), 141$153,1985$.

455 Davies, M. C. R., Hamza, O., and Harris, C.: The effect of rise in mean annual temperature on the stability of rock slopes containing ice-filled discontinuities, PERMAFROST PERIGLAC, 12(1), 137-144, 2001.

de Haas, T., Conway, S. J., and Krautblatter, M.: Recent (Late Amazonian) enhanced backweathering rates on Mars: Paracratering evidence from gully alcoves, J GEOPHYS RES-PLANET, 120(12), 2169-2189, 2015.

Deline, P., Kirkbride, M. P., Ravanel, L., and Ravello, M.: The Trê-la-Tête rockfall onto the Glacier de la Lex Blanche, Mont Blanc Massif, Italy, in September 2008, GEOGR FIS DIN QUAT, 31(2), 251-254, 2008.

Deline, P.: Interactions between rock avalanches and glaciers in the Mont Blanc massif during the late Holocene, QUATERNARY SCI REV, 28(11-12), 1070-1083, 2009.

Delmas, M., Calvet, M., and Gunnell, Y.: Variability of Quaternary glacial erosion rates - A global perspective with special reference to the Eastern Pyrenees, QUATERNARY SCI REV, 28(5-6), 484-498, 2009.

465 Draebing, D., Krautblatter, M., and Dikau, R.: Interaction of thermal and mechanical processes in steep permafrost rock walls: A conceptual approach, GEOMORPHOLOGY, 226, 226-235, 2014.

Draebing, D., Krautblatter, M., and Hoffmann, T.: Thermo-cryogenic controls of fracture kinematics in permafrost rockwalls, GEOPHYS RES LETT, 44(8), 3535-3544, 2017.

Draebing, D. and Krautblatter, M.: The Efficacy of Frost Weathering Processes in Alpine Rockwalls, GEOPHYS RES LETT, 470 46(12), 6516-6524, 2019.

Duca, S., Occhiena, C., Mattone, M., Sambuelli, L., and Scavia, C.: Feasibility of Ice Segregation Location by Acoustic Emission Detection: A Laboratory Test in Gneiss, PERMAFROST PERIGLAC, 25(3), 208-219, 2014.

Ewald, A., Hartmeyer, I., Keuschnig, M., Lang, A., and Otto, J.-C.: Fracture Dynamics In An Unstable, Deglaciating Headwall, Kitzsteinhorn, Austria, EGU General Assembly, Vienna, Austria, 7-12 April 2019, EGU2019-3055, 2019.

475 Fischer, A., Olefs, M., and Abermann, J.: Glaciers, snow and ski tourism in Austria's changing climate, ANN GLACIOL, 52(58), 89-96, 2011a.

Fischer, L., Kääb, A., Huggel, C., and Noetzli, J.: Geology, glacier retreat and permafrost degradation as controlling factors of slope instabilities in a high-mountain rock wall: the Monte Rosa east face, NAT HAZARD EARTH SYS, 6(5), 761-772, 2006. Fischer, L., Eisenbeiss, H., Kääb, A., Huggel, C., and Haeberli, W.: Monitoring topographic changes in a periglacial high480 mountain face using high-resolution DTMs, Monte Rosa East Face, Italian Alps, PERMAFROST PERIGLAC, 22(2), 140152, $2011 \mathrm{~b}$.

Gardner, J. S.: Evidence for Headwall Weathering Zones, Boundary Glacier, Canadian Rocky Mountains, J GLACIOL, 33(113), 60-67, 1987. 
https://doi.org/10.5194/esurf-2020-8

Preprint. Discussion started: 9 March 2020

(c) Author(s) 2020. CC BY 4.0 License.

Girard, L., Gruber, S., Weber, S., and Beutel, J.: Environmental controls of frost cracking revealed through in situ acoustic emission measurements in steep bedrock, GEOPHYS RES LETT, 40(9), 1748-1753, 2013.

Gischig, V. S., Moore, J. R., Evans, K. F., Amann, F., and Loew, S.: Thermomechanical forcing of deep rock slope deformation: 1. Conceptual study of a simplified slope, J GEOPHYS RES-EARTH, 116(F4), 2011.

Grämiger, L., Moore, J. R., Gischig, V. S., Ivy-Ochs, S., and Loew, S.: Beyond debuttressing: Mechanics of paraglacial rock slope damage during repeat glacial cycles, J GEOPHYS RES-EARTH, 122(4), 1004-1036, 2017.

490 Grämiger, L., Moore, J. R., Gischig, V. S., and Loew, S.: Thermomechanical Stresses Drive Damage of Alpine Valley Rock Walls During Repeat Glacial Cycles, J GEOPHYS RES-EARTH, 123(10), 2620-2646, 2018.

Grant, D., Bethel, J., and Crawford, M.: Point-to-plane registration of terrestrial laser scans, ISPRS J PHOTOGRAMM, 72, 16-26, 2012.

Gruber, S., Hoelzle, M., and Haeberli, W.: Rock-wall temperatures in the Alps: modelling their topographic distribution and regional differences, PERMAFROST PERIGLAC, 15(3), 299-307, 2004.

Gruber, S., and Haeberli, W.: Permafrost in steep bedrock slopes and its temperature-related destabilization following climate change, J GEOPHYS RES-EARTH, 112(F2), 2007.

Haberkorn, A., Phillips, M., Kenner, R., Rhyner, H., Bavay, M., Galos, S. P., and Hoelzle, M.: Thermal regime of rock and its relation to snow cover in steep alpine rock walls: Gemsstock, Central Swiss Alps, GEOGR ANN A, 97(3), 579-597, 2015.

500 Haeberli, W., Hoelzle, M., Paul, F., and Zemp, M.: Integrated monitoring of mountain glaciers as key indicators of global climate change: the European Alps, ANN GLACIOL, 46, 150-160, 2007.

Hales, T. C. and Roering, J. J.: A frost "buzzsaw" mechanism for erosion of the eastern Southern Alps, New Zealand, GEOMORPHOLOGY, 107(3-4), 241-253, 2009.

Hall, K.: The role of thermal stress fatigue in the breakdown of rock in cold regions, GEOMORPHOLOGY, 31(1-4), 47-63, 1999.

Hallet, B., Walder, J. S., and Stubbs, C. W.: Weathering by segregation ice growth in microcracks at sustained subzero temperatures: Verification from an experimental study using acoustic emissions, PERMAFROST PERIGLAC, 2(4), 283-300, 1991.

Hartmeyer, I., Keuschnig, M., and Schrott, L.: A scale-oriented approach for the long-term monitoring of ground thermal 510 conditions in permafrost-affected rock faces, Kitzsteinhorn, Hohe Tauern Range, Austria, AUSTRIAN J EARTH SCI, 105(2), 128-139, 2012.

Hartmeyer, I., Keuschnig, M., Delleske, R., Krautblatter, M., Lang, A., Schrott, L., and Otto, J.-C.: Enhanced rockwall retreat and modified rockfall magnitudes/frequencies in deglaciating cirques from a 6-year LiDAR monitoring, EARTH SURF DYNAM, submitted.

515 Hasler, A., Gruber, S., and Beutel, J.: Kinematics of steep bedrock permafrost, J GEOPHYS RES-EARTH, 117(F01016), 2012. 
https://doi.org/10.5194/esurf-2020-8

Preprint. Discussion started: 9 March 2020

(C) Author(s) 2020. CC BY 4.0 License.

Hoeck, V., Pestal, G., Brandmaier, P., Clar, E., Cornelius, H., Frank, W., Matl, H., Neumayr, P., Petrakakis, K., Stadlmann, T., and Steyrer, H.: Geologische Karte der Republik Österreich, Blatt 153 Großglockner, Geologische Bundesanstalt, Vienna, 1994.

520 Holm, K., Bovis, M., and Jakob, M.: The landslide response of alpine basins to post-Little Ice Age glacial thinning and retreat in southwestern British Columbia, GEOMORPHOLOGY, 57(3-4), pp.201-216, 2004.

Hooke, R. L.: Positive feedbacks associated with erosion of glacial cirques and overdeepenings, GEOL SOC AM BULL, 103(8), 1104-1108, 1991.

Hormes, A., Müller, B. U., and Schlüchter, C.: The Alps with little ice: evidence for eight Holocene phases of reduced glacier extent in the Central Swiss Alps, HOLOCENE, 11(3), 255-265, 2001.

Jia, H., Xiang, W., and Krautblatter, M.: Quantifying Rock Fatigue and Decreasing Compressive and Tensile Strength after Repeated Freeze-Thaw Cycles, PERMAFROST PERIGLAC, 26(4), 368-377, 2015.

Jia, H., Leith, K., and Krautblatter, M.: Path-Dependent Frost-Wedging Experiments in Fractured, Low-Permeability Granite, PERMAFROST PERIGLAC, 28(4), 698-709, 2017.

530 Kaser, G., Cogley, J. G., Dyurgerov, M. B., Meier, M. F., and Ohmura, A.: Mass balance of glaciers and ice caps: Consensus estimates for 1961-2004, GEOPHYS RES LETT, 33(19), 2006.

Kenner, R., Phillips, M., Danioth, C., Denier, C., Thee, P., and Zgraggen, A.: Investigation of rock and ice loss in a recently deglaciated mountain rock wall using terrestrial laser scanning: Gemsstock, Swiss Alps, COLD REG SCI TECHNOL, 67(3), 157-164, 2011.

535 Keuschnig, M., Hartmeyer, I., Höfer-Öllinger, G., Schober, A., Krautblatter, M., and Schrott, L.: Permafrost-Related Mass Movements: Implications from a Rock Slide at the Kitzsteinhorn, Austria, in: Engineering Geology for Society and Territory, edited by: Lollino, G., Manconi, A., Clague, J. Shan, W., and Chiarle, M., Springer International Publishing, 1(48), 255-259, 2015.

Keuschnig, M., Krautblatter, M., Hartmeyer, I., Fuss, C., and Schrott, L.: Automated Electrical Resistivity Tomography

540 Testing for Early Warning in Unstable Permafrost Rock Walls Around Alpine Infrastructure, PERMAFROST PERIGLAC, 28(1), 158-171, 2016.

Krautblatter, M., Funk, D., and Günzel, F.: Why permafrost rocks become unstable: a rock-ice-mechanical model in time and space, EARTH SURF PROC LAND, 38(8), 876-887, 2013.

Krautblatter, M. and Moore, J. R.: Rock slope instability and erosion: toward improved process understanding, EARTH SURF 545 PROC LAND, 39(9), 1273-1278, 2014.

Lague, D., Brodu, N., and Leroux, J.: Accurate 3D comparison of complex topography with terrestrial laser scanner: Application to the Rangitikei canyon (N-Z), ISPRS J PHOTOGRAMM, 82, 10-26, 2013.

Land Salzburg: Waldstandsaufnahme D, Bild 86-88, 24.08.1953, Salzburger Geographisches Informationssystem (SAGIS), Salzburg, Austria, 1953. 
https://doi.org/10.5194/esurf-2020-8

Preprint. Discussion started: 9 March 2020

(C) Author(s) 2020. CC BY 4.0 License.

Land Salzburg: Laserscanbefligung Bundesland Salzburg 2008, Salzburger Geographisches Informationssystem (SAGIS), Salzburg, Austria, 2008.

Leith, K., Moore, J. R., Amann, F., and Loew, S.: In situ stress control on microcrack generation and macroscopic extensional fracture in exhuming bedrock, J GEOPHYS RES-SOL EA, 119(1), pp.594-615, 2014.

Lewis, W. V.: A Melt-water Hypothesis of Cirque Formation, GEOL MAG, 75(6), 249-265, 1938.

555 Mair, R. and Kuhn, M.: Temperature and movement measurements at a bergschrund, J GLACIOL, 40(136), 561-565, 1994.

Manconi, A., Coviello, V., Galletti, M., and Seifert, R.: Short Communication: Monitoring rockfalls with the Raspberry Shake, EARTH SURF DYNAM, 6(4), 1219-1227, 2018.

Matsuoka, N. and Murton, J. B.: Frost weathering: recent advances and future directions, PERMAFROST PERIGLAC, 19(2), 195-210, 2008.

560 McColl, S. T. and Davies, T. R. H.: Large ice-contact slope movements: glacial buttressing, deformation and erosion, EARTH SURF PROC LAND, 38(10), 1102-1115, 2012.

Monserrat, O. and Crosetto, M.: Deformation measurement using terrestrial laser scanning data and least squares 3D surface matching, ISPRS J PHOTOGRAMM, 63(1), 142-154, 2008.

Moore, J. R., Sanders, J. W., Dietrich, W. E., and Glaser, S. D.: Influence of rock mass strength on the erosion rate of alpine cliffs, EARTH SURF PROC LAND, 34(10), 1339-1352, 2009.

Murton, J. B., Kuras, O., Krautblatter, M., Cane, T., Tschofen, D., Uhlemann, S., Schober, S., and Watson, P.: Monitoring rock freezing and thawing by novel geoelectrical and acoustic techniques, J GEOPHYS RES-EARTH, 121(12), 2309-2332, 2016.

Naylor, S. and Gabet, E. J.: Valley asymmetry and glacial versus nonglacial erosion in the Bitterroot Range, Montana, USA, GEOLOGY, 35(4), 375, 2007.

Noetzli, J., Huggel, C., Hoelzle, M., and Haeberli, W.: GIS-based modelling of rock-ice avalanches from Alpine permafrost areas, COMPUTAT GEOSCI, 10(2), 161-178, 2006.

Oskin, M. and Burbank, D. W.: Alpine landscape evolution dominated by cirque retreat, GEOLOGY, 33(12), 933, 2005.

Pelto, M. S.: Forecasting temperate alpine glacier survival from accumulation zone observations, CRYOSPHERE, 4(1), 67-

$57575,2010$.

Phillips, M., Wolter, A., Lüthi, R., Amann, F., Kenner, R., and Bühler, Y.: Rock slope failure in a recently deglaciated permafrost rock wall at Piz Kesch (Eastern Swiss Alps), February 2014, EARTH SURF PROC LAND, 42(3), 426-438, 2016. Plaesken, R., Keuschnig, M., and Krautblatter M.: Systematic derivation of anchoring forces in permafrost-affected bedrock, EGU General Assembly, Vienna, Austria, 23-28 April 2017, EGU2017-14476, 2017.

580 Purdie, H.: Glacier Retreat and Tourism: Insights from New Zealand, MT RES DEV, 33(4), 463-472, 2013.

Rabatel, A., Deline, P., Jaillet, S., and Ravanel, L.: Rock falls in high-alpine rock walls quantified by terrestrial lidar measurements: A case study in the Mont Blanc area, GEOPHYS RES LETT, 35(10), 2008. 
https://doi.org/10.5194/esurf-2020-8

Preprint. Discussion started: 9 March 2020

(C) Author(s) 2020. CC BY 4.0 License.

Ravanel, L. and Deline, P.: Climate influence on rockfalls in high-Alpine steep rockwalls: The north side of the Aiguilles de Chamonix (Mont Blanc massif) since the end of the 'Little Ice Age', HOLOCENE, 21(2), 357-365, 2010.

Ravanel, L., Deline, P., Lambiel, C., and Vincent, C.: Instability of a high alpine rock ridge: the lower arête des cosmiques, mont blanc massif, France, GEOGR ANN A, 95(1), 51-66, 2013.

Ravanel, L., Magnin, F., and Deline, P.: Impacts of the 2003 and 2015 summer heatwaves on permafrost-affected rock-walls in the Mont Blanc massif, SCI TOTAL ENVIRON, 609, 132-143, 2017.

Rosser, N. J., Petley, D. N., Lim, M., Dunning, S. A., and Allison, R. J.: Terrestrial laser scanning for monitoring the process of hard rock coastal cliff erosion, Q J ENG GEOL HYDROGE, 38(4), 363-375, 2005.

Rosser, N. J., Lim, M., Petley, D. N., Dunning, S. A., and Allison, R. J.: Patterns of precursory rockfall prior to slope failure, J GEOPHYS RES-EARTH, 112(F4), 2007.

Sanders, J. W., Cuffey, K. M., Moore, J. R., MacGregor, K. R., and Kavanaugh, J. L.: Periglacial weathering and headwall erosion in cirque glacier bergschrunds, GEOLOGY, 40(9), 779-782, 2012.

595 Sass, O.: Rock Moisture Fluctuations During Freeze-thaw Cycles: Preliminary Results from Electrical Resistivity Measurements, Polar Geography, 28(1), 13-31, 2004.

Sass, O.: Spatial patterns of rockfall intensity in the northern Alps, Z GEOMORPHOL, 138, 51-65, 2005.

Scherler, D., Bookhagen, B., and Strecker, M. R.: Hillslope-glacier coupling: The interplay of topography and glacial dynamics in High Asia, J GEOPHYS RES-EARTH, 116(F2), 2011.

600 Schober, A., Bannwart, C., and Keuschnig, M.: Rockfall modelling in high alpine terrain - validation and limitations / Steinschlagsimulation in hochalpinem Raum - Validierung und Limitationen, Geomechanics and Tunnelling, 5(4), 368-378, 2012.

Schrott, L., Otto, J.-C., and Keller, F.: Modelling alpine permafrost distribution in the Hohe Tauern region, Austria, AUSTRIAN J EARTH SCI, 105(2), 169-183, 2012.

605 Stoffel, M. and Huggel, C.: Effects of climate change on mass movements in mountain environments, PROG PHYS GEOG, 36(3), 421-439, 2012.

Supper, R., Ottowitz, D., Jochum, B., Römer, A., Pfeiler, S., Kauer, S., Keuschnig, M., and Ita, A.: Geoelectrical monitoring of frozen ground and permafrost in alpine areas: field studies and considerations towards an improved measuring technology, NEAR SURF GEOPHYS, 12(1), 93-115, 2013.

610 Terweh, S.: Geomorphologische Kartierung am Kitzsteinhorn (Hohe Tauern, Österreich) - Eine raum-zeitliche Analyse geomorphologischer Prozesse im Gletscherumfeld des Schmiedingerkees, Bachelor Thesis, University of Bonn, Germany, 67 pp., 2012.

Teza, G., Galgaro, A., Zaltron, N., and Genevois, R.: Terrestrial laser scanner to detect landslide displacement fields: a new approach, INT J REMOTE SENS, 28(16), 3425-3446, 2007. 
https://doi.org/10.5194/esurf-2020-8

Preprint. Discussion started: 9 March 2020

(c) Author(s) 2020. CC BY 4.0 License.

615 van Veen, M., Hutchinson, D. J., Kromer, R., Lato, M., and Edwards, T.: Effects of sampling interval on the frequency magnitude relationship of rockfalls detected from terrestrial laser scanning using semi-automated methods, LANDSLIDES, 14(5), 1579-1592, 2017.

Walder, J. S. and Hallet, B.: A theoretical model of the fracture of rock during freezing, GEOL SOC AM BULL, 96(3), 336, 1985 .

620 Walder, J. S. and Hallet, B.: The Physical Basis of Frost Weathering: Toward a More Fundamental and Unified Perspective, ARCTIC ALPINE RES, 18(1), 27, 1986.

Weber, S., Beutel, J., Faillettaz, J., Hasler, A., Krautblatter, M., and Vieli, A.: Quantifying irreversible movement in steep, fractured bedrock permafrost on Matterhorn (CH), CRYOSPHERE, 11(1), 567-583, 2017.

Weber, S., Beutel, J., Da Forno, R., Geiger, A., Gruber, S., Gsell, T., Hasler, A., Keller, M., Lim, R., Limpach, P., Meyer, M.,

625 Talzi, I., Thiele, L., Tschudin, C., Vieli, A., Vonder Mühll, D., and Yücel, M.: A decade of detailed observations (2008-2018) in steep bedrock permafrost at the Matterhorn Hörnligrat (Zermatt, CH), EARTH SYST SCI DATA, 11(3), 1203-1237, 2019. Wegmann, M., Gudmundsson, G., and Haeberli, W.: Permafrost changes in rock walls and the retreat of alpine glaciers: a thermal modelling approach, PERMAFROST PERIGLAC, 9(1), 23-33, 1998.

Williams, J. G., Rosser, N. J., Hardy, R. J., Brain, M. J., and Afana, A. A.: Optimising 4-D surface change detection: an 630 approach for capturing rockfall magnitude-frequency, EARTH SURF DYNAM, 6(1), 101-119, 2018.

WGMS: Global Glacier Change Bulletin No. 2 (2014-2015), edited by: Zemp, M., Nussbaumer, S. U., Gärtner-Roer, I., Huber, J., Machguth, H., Paul, F., and Hoelzle, M., ICSU(WDS)/IUGG(IACS)/UNEP/UNESCO/WMO, World Glacier Monitoring Service, Zurich, Switzerland, 244 pp., 2017.

Zemp, M., Frey, H., Gärtner-Roer, I., Nussbaumer, S. U., Hoelzle, M., Paul, F., Haeberli, W., Denzinger, F., Ahlstrøm, A. P., 635 Anderson, B., Bajracharya, S., Baroni, C., Braun, L. N., Cáceres, B. E., Casassa, G., Cobos, G., Dávila, L. R., Delgado Granados, H., Demuth, M., Espizua, L., Fischer, A., Fujita, K., Gadek, B., Ghazanfar, A., Ove Hagen, J., Holmlund, P., Karimi, N., Li, Z., Pelto, M., Pitte, P., Popovnin, V. V., Portocarrero, C. A., Prinz, R., Sangewar, C. V., Severskiy, I., Sigurđsson, O., Soruco, A., Usubaliev, R., and Vincent, C.: Historically unprecedented global glacier decline in the early 21 st century, J GLACIOL, 61(228), 745-762, 2015. 